\title{
Global Liquidity and Drivers of Cross-Border Bank Flows
}




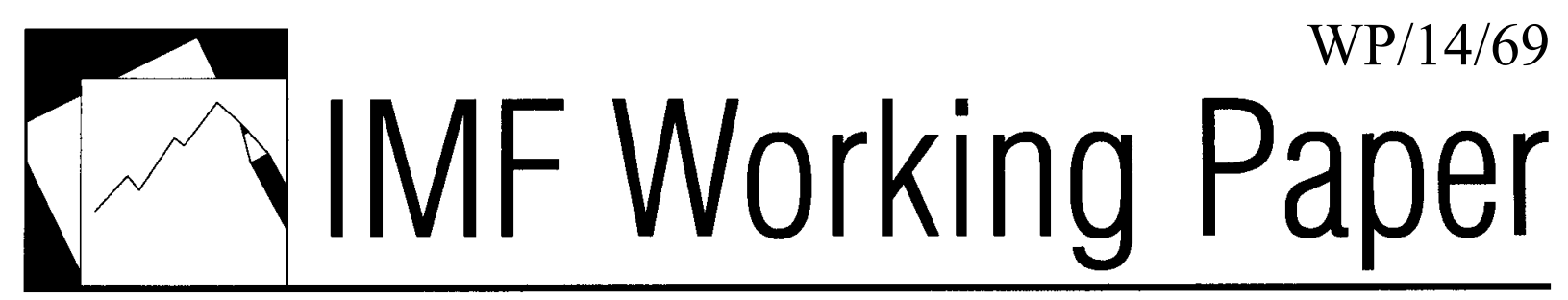

\section{Global Liquidity and Drivers of Cross-Border Bank Flows}

Eugenio Cerutti, Stijn Claessens and Lev Ratnovski 


\title{
IMF Working Paper
}

Research Department

\section{Global Liquidity and Drivers of Cross-Border Bank Flows* \\ Prepared by Eugenio Cerutti, Stijn Claessens and Lev Ratnovski}

April 2014

\section{This Working Paper should not be reported as representing the views of the IMF.}

The views expressed in this Working Paper are those of the author(s) and do not necessarily represent those of the IMF or IMF policy. Working Papers describe research in progress by the author(s) and are published to elicit comments and to further debate.

\begin{abstract}
This paper provides a definition of global liquidity consistent with its meaning as the "ease of financing" in international financial markets. Using a longer time series and broader sample of countries than in previous studies, it identifies global factors driving cross-border bank flows, alongside country-specific factors. It confirms the explanatory power of US financial conditions, with flows decreasing in market volatility (VIX) and term premia, and increasing in bank leverage, growth in domestic credit and M2. A new finding is that similar variables for other systemic countries - the UK and the Euro Area - are also important, sometimes even more so, consistent with the dominant role of European banks in cross-border banking. Furthermore, recipient country characteristics are found to affect not only the level of country-specific flows, but also the cyclical impact of global liquidity, with sensitivities of flows to banks decreasing with stronger macroeconomic frameworks and better bank regulation, but less so for flows to non-financial firms.
\end{abstract}

JEL Classification Numbers: Global Liquidity, International Banking, Capital Flows.

Keywords: F21, F34, G15, G18, G21, G28.

Author's E-Mail Addresses: ecerutti@imf.org; sclaessens@imf.org; 1ratnovski@imf.org.

\footnotetext{
* We would like to acknowledge helpful comments and suggestions from Olivier Blanchard, Pragyan Deb, Gaston Gelos, Brenda González-Hermosillo, Karl Habermeier, Jaume Puig, Edouard Vidon, and other IMF colleagues. Yangfan Sun provided excellent research assistance.
} 


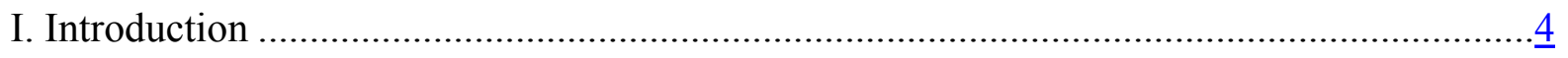

II. Definition and Literature Review......................................................................... $\underline{6}$

A. What is global liquidity? ......................................................................... $\frac{6}{7}$

B. What are the determinants of global liquidity? .................................................

III. Data and Empirical Analysis ...............................................................................

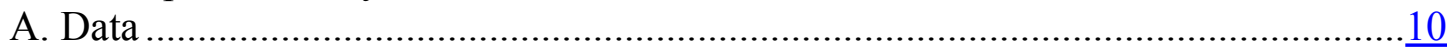

B. Empirical specification.......................................................................... $\frac{11}{12}$

C. Base regression results ....................................................................

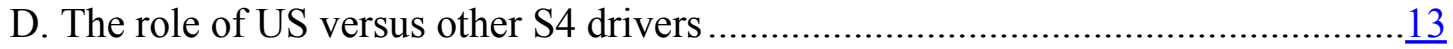

E. Borrowers' characteristics and the impact of global liquidity drivers ...................

IV. Conclusions and Policy Implications............................................................. 17

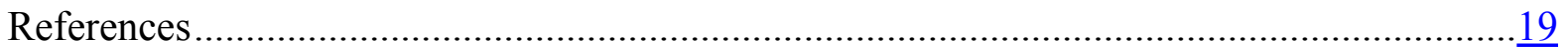

Annex A. Time series charts of the drivers of global liquidity.......................................

Tables

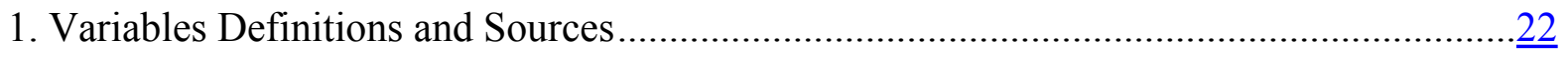

2. Summary Statistics, Correlations over Full Sample (1990Q1-2012Q4) and Regional

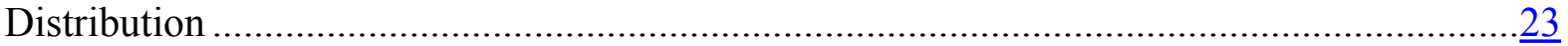

3. Summary Statistics and Correlations over the Period 2001Q1-2012Q4 for Individual S4

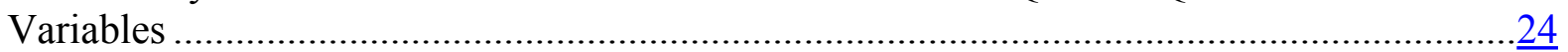

4. Regression Results for Cross-Border Claims to Banks and Non-Banks, for period 1990Q1-

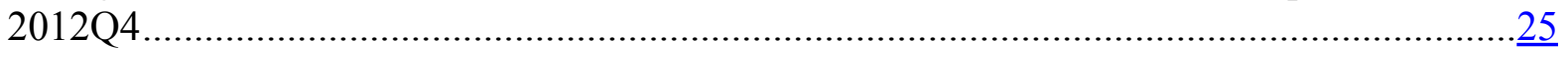

5. Regression Results for Cross-Border Claims to Banks and Non-Banks, Individual S4

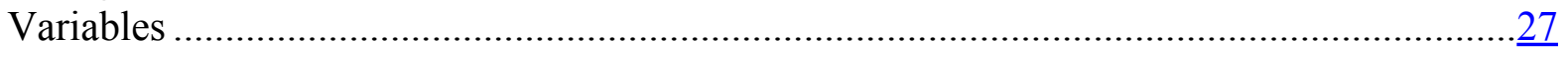

6. Regression Results for Cross-Border Claims to Banks and Non-Banks, Individual S4 Variables by Region..........................................................................................

7. Interaction Effects of Country Characteristics with Global Liquidity Variables ................29 


\section{INTRODUCTION}

The global financial crisis has illustrated how easily financial shocks can be transmitted in an interconnected world. Global gross capital inflows fell from 20\% of global GDP at their peak in 2007 to $1.3 \%$ in 2009 , and the total stock of cross-border bank claims fell by a third, from $52 \%$ of global GDP in 2007 to 38\% in 2012. Some recipient countries saw even larger contractions, resulting in major macroeconomic adjustments and financial turmoil. The world has experienced similar capital flow boom and bust episodes, albeit smaller, before (e.g., see IMF, 2013b). In many of these episodes, capital flows comoved significantly across recipient economies, which has led to the use of the concept "global liquidity." The idea is that much of the variation in flows is driven not by borrower country characteristics, but by global supply factors that alter the ease of funding in international markets.

Much of the research on global liquidity and cross-border financing conditions is recent, with still many conceptual and empirical gaps in our understanding (see Landau, 2013, and IMF, 2014a, for recent reviews of the state of knowledge). This paper attempts to fill some gaps most critical for formulating effective economic policy. It focuses on cross-border bank flows, given their importance in total capital flows and their at times volatile behavior (IMF, 2011). It builds on the previous literature on global factors in cross-border flows, which has identified the importance of uncertainty and risk aversion, monetary policy stance in source economies, and funding conditions and risk attitudes of global banks in affecting flows (Rey, 2013; Bruno and Shin, 2014).

Using a comprehensive dataset covering 77 recipient countries over the period 1990-2012 and adjusting for exchange rate changes, our analysis confirms most of the earlier results, also showing that most of the relations appear in the 2000s' financial globalization period. It then adds to the existing knowledge by exploring the following three questions:

- Where do global liquidity supply factors originate? The presumption in the literature, and the evidence documented to date, has been that factors driving global liquidity are predominantly US-centric. The question arises, however, whether financial conditions in other major source economies - the UK, Euro Area, and Japan (which, together with the US, can be called the systemic four or "S4") - play a role as well. We find that UK and Euro Area supply factors indeed play important roles globally, i.e., going beyond influencing regional flows (e.g., Western Europe to Eastern Europe), with the importance often exceeding that of US supply factors. This is consistent with the large global role of UK and Euro Area banks, including in transmitting financing from US to the rest of the world (cf. Shin, 2012; Rey, 2013). And this casts doubt on the presumption of many observers that the global financial cycle is predominantly driven by US financial sector and monetary conditions. 
- What measures of financial and monetary policy conditions in various source economies are the most relevant for cross-border bank flows? The literature offers mixed evidence on what the best measures are. While short-term interest rates and growth in money aggregates in some (notably US) source economies have been found to have explanatory power by some studies, the economic channels through which they affect flows remain unclear. Consistent with the weak theoretical priors, we find that short-term interest rates and growth in money aggregates are not robust in explaining cross-border bank flows across the S4 countries and various specifications. The slope of the (sovereign) yield curves in the US, UK and Euro Area, in contrast, has a robustly negative association with flows, consistent with its theoretical impact on banks' incentives to engage in a "search for yield." (Banks borrow short-term and lend long-term, so their domestic investment opportunities are less profitable when the yield curve is flat.) We also propose two new proxy measures for global liquidity drivers - bank leverage in non-US S4 countries (complementing US dealer bank leverage, as used in Bruno and Shin, 2014) and real domestic credit growth in S4 countries - and find them to be robustly and positively associated with cross-border bank flows (except for Japan). The credit growth measure is often used in the established literature on financial cycles (Borio et al 1994; Claessens et al. 2012a), and can be seen as an alternative for the bank leverage variable, for which long time series are only available for the US.

- What are the country-specific characteristics that affect the recipient economy's exposure to variations in global liquidity? In light of the large cross-border effects of financial conditions in key source countries and the de facto limited international coordination, recipient countries face the question of how best to adapt their own policies and institutions. We find that, not surprisingly, better institutions in recipient countries are associated with higher gross cross-border bank flows to both bank and non-bank borrowers. More stringent bank capital regulation reduces cross-border flows to banks, while capital controls reduce cross-border flows to non-bank borrowers. Importantly, certain country characteristics - more flexible exchange rate regime and stricter capital controls - reduce the cyclical impact of global liquidity on flows to banks and non-banks. And more stringent bank capital regulation, more supervisory powers and more restrictions on foreign bank presence reduce the cyclical impact of global liquidity on flows to banks (but not that on flows to non-banks). The fact that the significance of some recipient country policies is higher for flows to banks than for those to non-banks is consistent with banks being more regulated and public policy having limitations in controlling activities of non-bank borrowers. The estimated economic effects are substantial. For example, when US dealer bank leverage increases from the $25^{\text {th }}$ to the $50^{\text {th }}$ percentile, a country with low scores on the indexes for any of these dimensions (e.g., capital controls at the $25^{\text {th }}$ percentile) would experience growth in cross-border flows of about 20 percent, while a country with higher restrictions and regulations (at the 
$75^{\text {th }}$ percentile) only about a $11^{1 / 2}$ percent pick up on average. The magnitudes are somewhat lower for cross-border flows to non-bank borrowers (the growth in bank claims changes from $13 \frac{1}{2}$ to $7 \frac{1}{2}$ percent).

Our results have important bearing on the current policy debates on global financial cycles and global liquidity. They suggest that domestic financial conditions in all major source economies, not just the US, could affect the rest of the world through changes in cross-border bank flows. In light of the current asynchronous (conduct of and exit from) unconventional monetary policies in the $\mathrm{S} 4$ and other major economies, this finding alone is of major policy interest. Major economies may want to consider some of the effects their policies have on other countries as these can feed back on their own economies and financial systems. Whether mechanisms can be designed for major source economies to internalize the externalities on other countries is doubtful, but since some of the same factors that affect cross-border flows can also drive volatility in domestic credit, it might be in their own interests to consider these factors anyhow. And, even with the limited scope in practice for international policy coordination, results suggest that recipient countries have some policy options to reduce their exposure to global liquidity. Notably, by strengthening their macroeconomic management and regulatory environments, recipient countries can reduce the cyclical impact of global liquidity on cross-border bank flows.

The paper proceeds as follows. Section 2 introduces the concept of global liquidity and puts our analysis in the context of the existing theoretical and empirical literature. Section 3 describes the data and the empirical methodology and presents the results. Section 4 concludes, including with broader lessons and outstanding issues for policy and research.

\section{DEFINITION ANd Literature ReVIEW}

\section{A. What is global liquidity?}

Global liquidity has been discussed extensively, its dynamics have been explored in recent academic and applied work (see inter alia IMF, 2010, 2013, 2014a; and CGFS, 2011), and the BIS has started monitoring a selection of indicators - including price, flow, and stock measures - in semi-annual updates (BIS, 2013). Much of the literature on global liquidity and its impact on cross-border bank flows, however, has been data-driven. So it is useful to take a step back and introduce some structure by more formally defining the concept.

The starting point is that the expression "global liquidity" is commonly used to refer to the "ease of funding" in global financial markets, thus referring to supply factors. One can therefore think in terms of the supply of funds from reserve currency economies (here, S4) to 
other advanced economies and emerging markets. And then to define "global liquidity" as a vector of factors, $S$, which shift the supply function for cross-border credit out or in.

Formally, $\mathrm{Q}^{\mathrm{S}}=\mathrm{Q}(\mathrm{P}, \mathrm{S})$, where $\mathrm{Q}^{\mathrm{S}}$ is the quantity of financing provided, $\mathrm{P}$ is the "price" of this financing (say, expected return differentials, adjusted for country specific risks); and $S$ are a vector of "non-price" supply factors. Note that defining global liquidity this way can be seen as a specific case of funding liquidity (ease of financing, as in e.g., Brunnermeier and Pedersen, 2009). And that this definition is quite different from the notion of asset market liquidity, that is, the ability to trade rapidly with small price impacts. See further IMF (2014a) for a broader analysis of the concept of global liquidity and a review of the literature.

\section{B. What are the determinants of global liquidity?}

Non-price supply factors $S$ reflect financial conditions, risk attitudes and other conditions facing the providers of funds to cross-border markets. In our case, these providers are mainly major international banks. There are a number of indicators which the empirical literature has found relevant for describing their conditions and attitudes, and resulting impact on crossborder bank flows. For some of the indicators, we understand clear economic and financial channels. For others, channels are less clear. And some $S$ factors originate in the private sector, while others are derivatives of monetary policy, micro- and macroprudential policy stances (e.g., risk-taking induced by interest rate structures). The indicators notably identified in the existing theoretical and empirical literature can be classified as follows:

- Uncertainty and risk aversion in financial markets. Uncertainty and risk aversion are determined by multiple factors - macroeconomic fundamentals, lenders' and investors' risk attitudes (which can give rise to risk-on / risk-off episodes), and possibly the policy stance (accommodative monetary policy reduces uncertainty and risk aversion, Bekaert et al., 2013). In the empirical literature, uncertainty and risk aversion are commonly captured through the US VIX, the stock option prices-based measure of implied volatility (Rey, 2013).

- The funding conditions for global banks. Funding conditions also reflect risk perceptions, and affect the banks' ability and willingness to take on risks in (cross-border) lending. There are here a number of measures used in the literature. One is the TED spread (the difference between short-term interbank lending and government bond rates). Another is bank leverage, often taken as that of major US dealer banks; with the idea that high leverage indicates lower perceived risk and higher willingness and capacity of banks to lend (Adrian and Shin, 2010; Bruno and Shin, 2014).

- Money aggregates. The empirical literature also points out that changes in narrow money aggregates, such as M2, may affect the buoyancy of banks' cross-border lending, 
although the exact channel for this is unclear. One argument may be that the growth in some components of broad money measures, such as wholesale or non-financial enterprises' deposits, can complement leverage measures in explaining bank risk as they indicate the relative ease of funding conditions (Hahm, Shin and Shin, 2013; Chung et al., 2014).

- Monetary policy in S4. This includes the general level of interest rates (rather than relative, as in spreads) and the slope of the yield curve. Although the effect of low interest rates on bank risk taking is supported by some empirical literature (Altunbas et al., 2014; Borio and Zhu, 2012; Jimenez et al., 2014; Bruno and Shin, 2013, 2014), its economic significance and precise causal channels remain the subject of much debate. In contrast, the effect of the slope of the yield curve on bank risk taking has a clear economic intuition. Banks borrow short-term and lend long-term, so their domestic investment opportunities are less profitable when the yield curve is flat; this may trigger banks' search for yield, including in the form of cross-border bank loans.

- Financial regulation and innovation. Stringent micro- and macroprudential regulation may limit bank risk-taking, particularly in upturns, reducing (cross-border) lending and making it less volatile. Higher capital requirements may directly dampen bank lending, including its cross-border component (Aiyar et al., 2013). Financial innovation, such as the development of short-term funding markets (as through the shadow banking system, see Claessens et al., 2012b), on the other hand may increase the volatility of cross-border lending, as the reliance on these fragile markets makes bank funding more volatile.

Note that, in principle, all of the above channels could affect both domestic and cross-border lending of banks. But cross-border lending can be expected to be the more volatile of the two, i.e., expand and contract more at the margin as financial conditions change. This is because of higher asymmetric information (which may affect lending especially during downturns), more reliance on hard information (which makes cross-border lending scalable up or down), and the additional considerations of country and sovereign risk factors (which may also vary over the cycle).

It is also useful to place our paper in the context of recent notable contributions to the global liquidity literature. Bruno and Shin (2014) focus on the role of US dealer bank leverage and other US bank conditions in determining global liquidity. We complement their work by using additional measures - overall bank leverage and real credit growth in S4 countries which are similar in economic effects but more widely available. We also offer evidence based on a longer time series, distinguish among S4 countries (which helps clarify some of their results, e.g. on the role of money growth), and study in more detail the role of recipient country characteristics. Rey (2013) focuses on VIX as a driver of the global liquidity cycle and suggests that capital controls may be essential to ensure independence of domestic 
monetary policy, even for countries with flexible exchange rate regimes. We empirically confirm the results on the effect of capital controls, but also identify a role for other tools, such as stricter bank regulation and supervision, to mitigate the cyclical impact of global liquidity. And our analysis of the importance of recipient country characteristics draws on the earlier, broader literature on "push" and "pull" factors, which has attempted to explain the determinants of cross-border capital flows using global factors such as global interest rates, and countries' growth rates, inflation and institutional characteristics (e.g., Calvo et al., 1996; and more recently Fratzscher, 2011, and Brandao et al., 2013). ${ }^{2}$

Against this background, the specific contributions of the paper are three-fold. First, we study a longer period with more recipient countries than many previous studies have done, and also analyze the effects of global liquidity drivers on cross-border lending to banks as well as to non-banks, using in all cases exchange rate adjusted data. ${ }^{3}$ Second, we distinguish between drivers of global liquidity originating in different S4 countries, an issue of current interest given the asynchronous nature of unconventional monetary policy measures in these countries. And third, we consider how borrower country characteristics can affect countries' exposures to variations in global liquidity drivers.

\section{DATa AND EMPIRICAL ANALYSIS}

Following the definition provided in the previous section, the objectives of this section are to document which drivers of global liquidity, for the US and other S4 countries, help explain the evolution of cross-border bank claims on banks and non-banks over the period 19902012. In addition, we investigate which borrower countries' policies and characteristics (e.g., exchange rate regime, participation of foreign banks in domestic banking sector, banking regulation, etc.) play a role in dampening or amplifying the impact of global liquidity indicators on cross-border bank lending.

\footnotetext{
${ }^{2}$ Among other relevant papers, Eickmeier et al. (2013) use principal components analysis to identify common factors in a broad range of country-specific series of various financial variables. As a few factors can statistically account for much of the variability in the data, global factors are then thought to drive in large part the cross-border flows. Controlling for demand at the recipient country level, Cerutti and Claessens (2014) identify shocks to major banking systems' balance sheets to be important global supply factors. See also IMF (2014b).

${ }^{3}$ Since BIS banking statistics are reported in US dollars, a time series analysis of cross-border bank flows is better performed using exchange rate adjusted data in order to capture changes in the actual underlying positions of bank claims rather than also variations in bank claims due to exchange rate movements.
} 


\section{A. Data}

Our data on cross-border bank exposures is from the BIS International Banking Statistics (IBS), which provides a comprehensive picture of cross-border banking linkages across countries. The BIS IBS comprises two datasets - the Locational and the Consolidated banking statistics. ${ }^{4}$ These datasets capture the exposures (i.e., loans, securities, and other claims) of the most important banking systems vis-à-vis their borrowers in any country in the world. Our analysis is based on the BIS Locational data (BIS IBS Table 6) since those data confirm closer to the notion that conditions in specific source countries affect flows.

Furthermore, there are two data-related reasons: (i) the BIS Locational data provides a long time span, much longer than the BIS Consolidated banking statistics (often only consistently available from the mid-2000s); and (ii) it provides exchange rate adjusted series for the sectoral breakdown of banks and non-banks. The data series used covers the period 19902012, includes 77 countries, and breaks down the evolution of (exchange rate adjusted) cross-border bank claims on bank and non-bank borrowers.

We capture the drivers of global liquidity through the measures suggested by theoretical and empirical studies. Specifically, we use the stock option market implied volatility (e.g., CBOE VIX for the US), US dealer bank leverage, S4 bank leverage and real credit growth, TED spreads ( 3 month Libor minus 3 month government bond yield), slope of yield curve (10 year government bond yield minus 3 month government bond yield), real policy rate (policy rate deflated with CPI), and monetary aggregates. These measures are compiled separately for each of the S4, that is, for the US, UK, Euro Area, and Japan (see Figures in the Appendix). In addition to these widely-used measures, we explore two new measures of credit conditions in advanced economies - bank leverage and credit growth, which are available for multiple S4 countries and complement the US dealer bank leverage measure of Bruno and Shin (2014).

Borrower country demand and creditworthiness factors are also included, specifically (lagged) GDP growth rate and inflation as well as the change in the differential between the local and international interest rates. We also include in our regressions as controls a number of other borrower characteristics, specifically indexes of the flexibility of the exchange rate regime, the presence (or lack thereof) of capital controls, the overall institutional

\footnotetext{
${ }^{4}$ BIS Locational banking statistics are residence-based data (i.e. they follow balance-of-payments accounting), and track the cross-border positions of banks located in a particular country. Both domestically-owned and foreign-owned banking offices in the reporting countries record their positions on a gross (unconsolidated) basis, including positions vis-à-vis own affiliates in other countries.BIS Consolidated statistics track banks' worldwide consolidated gross claims and other exposures to individual countries and sectors. Banks net out intergroup positions and consolidate positions across offices worldwide in the BIS consolidated statistics.
} 
environment quality, and various indexes of banking regulation (the strengths of capital adequacy requirements and of supervisory powers, and limits on foreign bank presence).

Table 1 provides definitions and sources of the variables, while Tables 2 and 3 provide raw statistics and correlation matrixes for the whole period and by sub-periods. Table 3 also provides in Panel B the correlations among each of the S4 specific drivers, showing high correlations for most cases, but relatively low or negative for some series (e.g., Japan M2 with other S4 M2).

\section{B. Empirical specification}

The base estimation consists of a panel regression with country fixed effects and standard errors clustered at the borrower country level:

$$
\Delta L_{j t}=\beta_{0}+\beta_{1} \text { DomesticFactor }_{j t}+\beta_{2} \text { InterestSpread }_{j t}+\beta_{3} \text { GlobalLiquidity }_{t}+\gamma_{j}+\varepsilon_{j t}
$$

where the dependent variable $\Delta \mathrm{L}_{\mathrm{jt}}$ is the quarterly log difference in the exchange rate adjusted stock of bank claims in borrower country j at time t; Domestic Factor ${ }_{j t}$ are the proxies for country $\mathrm{j}$ demand at $\mathrm{t}$; $\Delta$ InterestSpread $_{\mathrm{jt}}$ is the change (current quarter minus 4 quarter lag) in the spread between local lending rates and US Fed Funds Rate; Global Liquidity $_{t}$ is the set of $\mathrm{S} 4$ global liquidity drivers at time $\mathrm{t}$; and $\gamma_{\mathrm{t}}$ are country fixed effects. Two different dependent variables are used: (i) the change in the stock of BIS Locational cross-border claims on the banking sector of borrower country $\mathrm{j}$, and (ii) the change in the stock of BIS Locational cross-border claims on the non-bank sector of borrower country $j$. We use the terms "change in cross-border bank lending" or "flows" as short hand for these variables.

We then introduce country characteristics and interaction variables to analyze the factors that can affect the potential impact (level or cyclicality) of global liquidity indicators on crossborder bank lending. Specifically:

$\Delta L_{j t}=\beta_{0}+\beta_{1}$ DomesticFactor $_{j t}+\beta_{2} \Delta$ InterestSpread $_{j t}+\beta_{3}$ Global Liquidity $_{t}$ $+\beta_{4}$ BorrowerCharacteristics $_{j t}+\beta_{5}$ Global Liquidity $_{t}{ }^{*}$ BorrowerCharacteristics $_{j t}+\gamma_{j}+\varepsilon_{j t}$

where BorrowerCharacteristics $s_{j t}$ captures our selected borrower characteristics: (i) type of exchange rate regime, (ii) use of capital controls; (iii) general institutional development (rule of law, investment risks, etc.); and (iv) bank regulatory variables. 


\section{Base regression results}

The base regression results indicate that country characteristics proxying demand and creditworthiness - lagged GDP growth and lagged inflation - are statistically significant factors in explaining cross-border lending to banks (Table 4, Panel A). This holds for the whole period under study, 1990-2012 (columns 1 to 11), and for several sub-periods (columns 12 to 14). Similarly, lagged GDP (positive) and to a lesser extent lagged inflation (negative) are statistically significant in explaining flows to non-bank borrowers (Table 3, Panel B). The coefficients of the changes in interest differentials are not statistically different from zero in the full sample. This may be in part due to the sample coverage which includes many developing countries where interest rates are often not market-based. ${ }^{5}$

As the existing literature has highlighted (e.g., McGuire and Tarashev, 2008; Avdjiev et al., 2012; Bruno and Shin, 2014; Cerutti, 2013; Turner 2014), we confirm that US global liquidity indicators (CBOE VIX, TED Spread, credit growth, dealer bank leverage, real interest rate, slope of the yield curve, as well as M2 growth in S4) are statistically significant drivers of cross-border bank claims when considered individually (see columns 2 to 8 in Panel A and B). VIX and TED spreads have the expected negative signs, indicating that higher risk is associated with lower growth in cross-border bank claims, and US dealer bank leverage the expected positive sign, showing that banks expand more cross-border when their leverage is high. Also real US credit growth has a statistically significant positive sign, possibly as it captures the leverage and financial cycle.

The level of the US real interest rate has a positive sign, indicating that during less favorable US economic conditions - when interest rates are lower, global banks provide fewer crossborder loans. This contrasts with the view that low rates increase bank risk-taking, which has been highlighted in some recent papers, but does not seem to dominate over this longer period. The US yield curve slope has a negative coefficient, suggesting the presence of "search for yield" incentives in global banks: when US investment opportunities are more attractive, cross-border flows decline. M2 growth in S4 countries is statistically significant and positively associated with cross-border flows.

Since the correlations among the individual US drivers are moderate in our sample (except for the correlation between dealer bank leverage and real credit growth, and between the policy rate and the slope of the yield curve, see Table 2), we run regressions that include

\footnotetext{
${ }^{5}$ When the sample is reduced to advanced and large emerging markets, these coefficients become statistically significant, with the signs mostly negative, indicating that larger differentials deter rather than encourage crossborder bank flows (e.g., suggesting higher local rates lead to perceptions of more risk).
} 
most drivers simultaneously. The results (columns 9-11 in Table 4, Panels A and B) show that the VIX and US dealer bank leverage remain statistically significant determinants of changes in cross-border claims on banks and non-banks. M2 growth is a significant determinant of claims on banks, while the slope of the yield curve of claims on non-banks. There is evidence that VIX and dealer bank leverage are associated with larger changes in cross-border claims on banks (Panel A) than those on non-bank borrowers (Panel B), suggesting that intra-banking system flows are more sensitive to financial conditions compared to flows to non-banks.

The economic effects implied by the marginal effects highlight the role of VIX and US dealer bank leverage in driving cross-border bank flows. A change in the VIX from the $25^{\text {th }}$ to the $50^{\text {th }}$ percentile implies an annual reduction in cross-border bank claims on banks of $53 / 4$ percent ( $3 \frac{1}{2}$ percent for non-banks). Similarly, a change in the US dealer bank leverage from the $25^{\text {th }}$ to the $50^{\text {th }}$ percentile implies an annual increase of $51 / 2$ percent in claims on banks ( $4 \frac{1}{2}$ percent for non-banks). The economic effects of the other variables are of lower magnitude, except for the borrowing country GDP growth, where moving from the $25^{\text {th }}$ to the $50^{\text {th }}$ percentile implies an increase of 3 percent in claims on banks ( $2 \frac{1}{4}$ percent for nonbanks).

Columns 11 and 12 show that the results for the full 1990-2012 sample (in column 9) are largely driven by the second sub-period (2001-2012). This is consistent with a greater degree of financial integration and globalization since the late 1990s. Interestingly, column 13 shows that the results for the pre-global financial crisis period (2001-2006) are similar to those for 2001-2012 (column 12). This makes clear that the crisis and its aftermath do not drive the main results.

\section{The role of US versus other S4 drivers}

Following the existing literature highlighted in Section II, we have used mostly US variables to capture the global drivers. An interesting and so far not explored question is whether US variables are the most relevant for capturing global liquidity. In recent decades, US banks have not been the largest cross-border lenders, with European (UK and Euro Area) banks most often representing a larger share of the cross-border banking. We compiled series on most of the drivers similar to the US series used in Table 4 for the UK, Euro Area, and Japan. Instead of dealer bank leverage, however, we use commercial bank leverage for the non-US S4. Many of these non-US S4 series are highly correlated with the US series and among each other within each driver category (see Table 3, panel B). They can thus not be simultaneously included in the estimations. For this reason, we compare their explanatory power individually. We also use a reduced sample of recipient countries, which excludes the US, UK, Japan and the Euro Area countries themselves, to capture cross-border impacts and not to bias results in favor of Euro Area drivers (that represent 16 recipient countries in the full 
dataset).

Table 5 displays the regression results for the individual S4 country drivers, introduced separately in panel regressions that also include again (but not reported) lagged recipient country GDP growth, lagged CPI inflation, and the change in interest rate differentials. These estimations are performed for the period 2001-2012, as the results presented in Table 4 were mostly driven by that period and because the data on most Euro Area liquidity drivers are consistently available for that period only. The table reports, besides the coefficients on the S4 drivers, only the R2s.

The results are similar across the $\mathrm{S} 4$ countries for the global liquidity drivers capturing risk aversion. All four VIX-type display significant negative coefficients, with the US VIX having slightly higher explanatory power (an R2 of 0.052, as shown in the third entry in the first cell in Table 4A, against the highest R2 of 0.046 for the other countries). No similarly common pattern is present in the case of TED spreads, real policy rates, or the slope of the yield curve. For TED spreads, not only is the US TED spread not significant, but the R2 of the regression using the UK TED spread is about twice that of the one using the US TED spread, and the R2s for the Euro Area and Japan TED spreads are also higher than that for the US TED spread. Whereas for cross-border claims on banks, the US and UK real policy rate and slope of the yield curve have similar coefficients, adding the UK variables provides more explanatory power than adding the US variables. The Euro Area policy rate is not statistically significant, but the slope of the yield curve is, with a coefficient similar to that for the US and UK. Japan is an exception in several ways: the policy rate is not significant, while the slope of the yield curve is significant but with a positive sign. The fact that the interest rate in Japan has been very low and has varied little over the period (Table 2) may partly be behind these regression results.

Bank leverage and credit growth in the UK and Euro Area have a statistically significant and positive effect on cross-border claims (similarly to what was already documented for the US). For Japan, bank leverage is positive but not statistically significant. This suggests that, except perhaps for Japan, bank leverage and real credit growth are useful proxies for the willingness of international banks to extend loans cross-border, and can complement the US dealer bank leverage measure traditionally used in the literature.

The results for the various S4 M2 measures in Table 5 are also insightful, particularly since the analytical basis for the impact of M2 on cross-border credit is less obvious. Recall that in Table 4 cross border claims increased in aggregate S4 M2 growth. Table 5 shows that this relationship also holds for UK and Euro Area M2 growth. But the sign flips to negative for US and Japan M2 growth. We interpret this as reflecting the greater importance of banks in overall financial intermediation for the UK and Euro Area, where an increase in bank 
deposits (part of M2) translates more directly into larger bank balance sheets and more crossborder lending. An increase in US and Japan M2 might not have the same effect, perhaps because growth in M2 there reflects in part flight to safety (i.e., occurs during periods of deleveraging and reductions in cross-border lending). Nevertheless, since European banks represent the largest share of overall cross-border bank flows over this period, and the evolution of UK and Euro Area M2 is driving a large part of the S4 M2 aggregate, the coefficient on aggregate S4 M2 growth in Table 4 was still positive.

In summary, the results indicate that US variables are not necessarily the most important global drivers of cross-border bank flows. This is especially so for cross-border claims on banks, where UK and (to a slightly lesser degree) Euro Area drivers have high explanatory powers, sometimes exceeding that of US drivers.

In principle, differences in explanatory power of the global liquidity drivers from different S4 countries could reflect regional effects, where individual S4 lenders may have dominant market shares for (groups of) borrower countries. For example, Euro Area (Japan) global drivers could be particularly relevant for European (Asian) borrowing countries. The regional effects of S4 conditions could be further amplified by regional macroeconomic feedback effects (e.g., through the trade channel). Since bilateral cross-border banking exposures are not available (due to confidentiality issues), we can only conduct a preliminary exploration of whether our results on the importance on non-US global liquidity factors hold beyond the regional effects. We do that by estimating separate regressions of individual S4 country drivers for the different geographical regions in our sample.

This analysis, reported in Table 6, indicates that individual S4 country drivers are most of the time significant for their own regions (e.g., Euro Area drivers are significant in explaining cross-border bank claims on non-Euro Area European countries). They also have, however, often explanatory power beyond their own regions. In some cases, such as for individual S4 VIX indexes, which are negatively significant across all regional specifications, it is not clear whether the non-US S4 country drivers have explanatory power by themselves, or simply reflect their high correlations with the equivalent US drivers (e.g., US VIX). However, for other non-US S4 country drivers, results suggest explanatory power above their correlations with US drivers and impact beyond their own region. One example is TED spreads. Unlike the US TED spread, UK, Japan, and Euro Area TED spreads were statistically significant in the estimations for the whole non-S4 sample in Table 5. The regional subsample regressions in Table 6 show that cross-border claims in Asian, European and the Western Hemisphere countries relate negatively not only to variations in their own regional S4 variables (e.g. Euro Area TED spread affecting flows to non-Euro Area European countries), but also to other TED spreads, mostly non-US. Similar patterns are present for the other global drivers, and these results hold for claims on both banks and non-bank borrowers. 


\section{E. Borrowers' characteristics and the impact of global liquidity drivers}

We next study whether borrower countries' policies and characteristics affect the level or volatility of cross-border bank inflows. Table 7 present the coefficients for the impact of country characteristics and of the interactions of country characteristics with key global liquidity drivers. The selection of the global liquidity drivers and S4 countries for the interaction effects was based on their explanatory powers in Table 5.

Table 7 shows, not surprisingly, that better institutions increase the growth in cross-border claims on banks and non-bank borrowers. Stricter bank capital regulation, a proxy for a banking system with higher (quality) buffers, reduces the growth in cross-border claims on banks. Capital controls reduce the growth in cross-border bank claims on non-bank borrowers, but to a lesser degree. Other country characteristics are mostly not statistically significant.

The interactions of country characteristics with specific global liquidity drivers - US VIX, UK TED spreads, UK real policy rate, UK slope of yield curve, S4 M2 growth rate, and global leverage - show that a more flexible exchange rate regime and/or stricter capital controls reduce the cyclical impact of global liquidity on cross-border claims on both banks and non-bank borrowers, as those interaction coefficients are statistically significant negative. Stricter capital regulation, more supervisory power, and more restrictions on foreign bank presence reduce the cyclical impact of global liquidity on claims on banks, but not that on claims on non-banks, across most global liquidity drivers. This suggests some role for country policies in reducing the cyclical impact of global liquidity on cross-border flows to banks, but not as much to non-banks, consistent with banks being more regulated and public policy having limitations in controlling activities of non-banks.

Even though recipient country characteristics and regulations do not fully insulate the country from variations in global liquidity, their estimated economic effects are substantial. For example, when US dealer bank leverage increases from the $25^{\text {th }}$ to the $50^{\text {th }}$ percentile, a country with a level of capital controls at the $25^{\text {th }}$ percentile would experience a growth in cross-border claims of about 19 percent, while a country with capital controls at the $75^{\text {th }}$ percentile would experience only about a 10 percent pick up. The magnitude is somewhat lower for cross-border claims on non-banks (here differential growth drops from 14 to 7 percent). Similar patterns are present for exchange rate flexibility (an increase in exchange rate flexibility decreases the impact of an increase in US bank leverage on cross-border bank flows from 22 percent to $9 \frac{1}{2}$ percent), institutional quality (a worsening in quality decreases the impact from 18 to 11 percent), and supervisory power (more power decreases the impact 
from 20 to 15 percent). ${ }^{6}$

\section{ConClusions ANd Policy IMPlications}

Using a long times series and a broad set of countries, this paper confirms that a number of global factors drive cross-border bank flows alongside country-specific factors. Cross-border bank flows decrease in volatility (VIX), and the slope of the US yield curve, but increase with US dealer bank leverage, real interest rates, and money growth. An important new finding is that financial conditions in other systemic countries, notably UK and Euro Area, also drive flows, and are sometimes more important in than equivalent US conditions. Furthermore, we find that both level and cyclicality of cross-border inflows depend on recipient country policies and characteristics. For example, a more flexible exchange rate and stricter bank regulation can serve as buffers against the cyclicality of flows.

Overall, our results clarify the existing literature, and bring to light a number of new aspects. Our paper confirms the importance of risk aversion measures in S4 for determining crossborder bank flows. It verifies the change in dealer bank leverage as an important measure (Bruno and Shin, 2014), and provides evidence of the usefulness of additional indicators of bank risk taking: overall bank leverage and the growth in real domestic credit (cf. Borio and Lowe, 2004). We find marginally robust effects of the growth in individual S4 countries narrow money aggregates on global liquidity. Since these effects are dominated in a horse race by the effects of individual S4 countries' bank leverage, it suggests that money aggregates may be relatively weak proxies of credit conditions. Contrary to theoretical priors, we find positive effects of the interest rate level in S4 countries on cross-border bank lending, although these are not consistent across specifications. The negative relationship between the term premium and cross-border claims is robust and fits priors more clearly. We also show that recipient country capital controls, stronger bank regulation and supervision, and a better macroeconomic framework, help manage the exposures to global liquidity (consistent with the earlier literature of push and pull factors, cf. Calvo et al., 1996; Claessens et al. 1998; and recent suggestions by Rey, 2013).

The broader lesson from the global liquidity literature is that cross-border flows can give rise to both benefits and risks. Global cyclical swings can add a welcome impetus and support local activity during times of stress. But they can also have undesirable procyclical effects. In the face of volatile global conditions, domestic monetary and fiscal policies can become less effective. Favorable global financial conditions can add to the build-up of vulnerabilities (e.g., asset price booms and related financial fragility, possibly leading to busts and resulting

\footnotetext{
${ }^{6}$ The fact that multiple recipient country characteristics can affect the exposure to variations in global liquidity expands the suggestions of Rey (2013) who focuses predominantly on the role of capital controls.
} 
in instability), especially in case of weaker macroeconomic and prudential policies in recipient countries. Overall, there may be a need to adapt policy responses, both domestically and globally. The global liquidity cycle is importantly driven by global systemic financial institutions, whose distress can propagate widely in the global economy. Monitoring liquidity, funding, and credit conditions in these institutions is therefore critically important.

The state of the art in understanding global liquidity is still limited, however, both regarding the channels through which financial conditions affect global investors' risk-taking, capital flows and ensuing vulnerabilities, and in determining how global liquidity is consequently best measured. A better understanding of the drivers of liquidity conditions in advanced economies, and the mechanisms of international propagation and related amplification of financial shocks is therefore sorely needed. In the meantime, the challenge for countries and others engaged in surveillance is to find empirically useful indicators that have sound conceptual underpinnings. Multiple indicators corresponding to various aspects of liquidity have been proposed over time and found to be useful in detecting vulnerabilities. Yet continuously changing institutional environments, evolving micro- and macro-prudential and other regulatory policies, ongoing financial innovations and shifting market structures, all keep reshaping the mechanics of liquidity creation and propagation. This reinforces a key lesson from earlier crisis episodes that a continuous review of indicators is warranted. 


\section{References}

Adrian, T., and H. S. Shin, 2010, "Liquidity and leverage," Journal of Financial Intermediation, 19(3), pp. 418-437.

Aiyar, S, C. W. Calomiris, J. Hooley, Y. Korniyenko, and T. Wieladek, 2013,'The International Transmission of Bank Capital Requirements: Evidence from the UK," Journal of Financial Economics, forthcoming.

Altunbas, Y., L. Gambacorta, and D. Marqués-Ibáñez., 2014, “Does monetary policy affect bank risk-taking?" International Journal of Central Banking, March, 10:1, 95-135.

Avdjiev, S., Z. Kuti, and E. Takats, 2012, "The Euro Area Crisis and Cross-border Bank Lending to Emerging Countries," BIS Quarterly Review, December.

Bank for International Settlements, 2013, “Global liquidity: selected indicators”, BIS website, http://www.bis.org/statistics/gli.htm

Bekaert, G., M. Hoerova, M., and M. Lo Duca. 2013, "Risk, uncertainty and monetary policy," Journal of Monetary Economics, 60 (7), pp. 771-788.

Borio, C.E., N. Kennedy and S. Prowse, 1994, "Exploring aggregate asset price fluctuations across countries: measurement, determinants and monetary policy implications", BIS Working Paper no 40, April.

Borio, C. E., and P. Lowe, 2004, "Securing sustainable price stability: should credit come back from the wilderness?” Working Paper No. 157, Bank for International Settlements.

Borio, C. E. and H. Zhu, 2012. "Capital regulation, risk-taking and monetary policy: A missing link in the transmission mechanism?," Journal of Financial Stability, 8(4), 236-251.

Brandao-Marques, L., G. Gelos, and N. Melgar, 2013. "Country Transparency and the Global Transmission of Financial Shocks”, IMF Working Paper No. 13/156.

Brunnermeier, M. K., and L.H. Pedersen, 2009, "Market liquidity and funding liquidity. Review of Financial studies", 22(6), 2201-2238.

Bruno, V., and H. S. Shin, 2013, "Capital flows and the Risk-Taking Chanel of Monetary Policy, Cross-border banking and global liquidity, " (No. w18942). National Bureau of Economic Research.

Bruno, V. and H. S, Shin, 2014, “Cross-Border Banking and Global Liquidity,” mimeo, Princeton University.

Calvo, G., L. Leiderman, and C. Reinhart. 1996. "Inflows of Capital to Developing Countries in the 1990s." Journal of Economic Perspectives 10(2): 123-139 
Cerutti, E., 2013, “Banks' Foreign Credit Exposures and Borrowers' Rollover Risks: Measurement, Evolution and Determinants," IMF Working Paper No. 13/9.

Cerutti. E., and S. Claessens, 2014, "The Great Cross-Border Bank Deleveraging: Supply Side Characteristics," mimeo, IMF, Washington, D.C.

Chung, K., J. E. Lee, E. Loukoianova, E., M. Park, and H. S, Shin, 2014, "Global liquidity through the lens of monetary aggregates," IMF Working Paper 14/9. (Washington: International Monetary Fund).

Claessens, S., P. Chuhan and N. Mamingi, 1998, "Equity and Bond Flows to Asia and Latin America. The Role of Global and Country Factors," Journal of Development Economics, 55: 439-63.

Claessens, S., Z. Pozsar, L. Ratnovski, and M. Singh, 2012a, "Shadow Banks: Economics and Policy", IMF Staff Discussion Note 12/12 (Washington).

Claessens, S., M. A. Kose, and M. Terrones, 2012b, "How Do Business and Financial Cycles Interact?" Journal of International Economics, 87(1), 178-190.

Committee on the Global Financial System (CGFS), 2011, "Global Liquidity-Concept, Measurement and Policy Implications," CGFS Papers no 45, December

Eickmeier, S., L. Gambacorta, and B. Hofmann, 2013, "Understanding global liquidity,” BIS Working Paper 402.

Fratzscher, M. 2011, "Capital flows, Push versus pull factors and the global financial crisis," ECB Working Paper No 1364.

Hahm, J. H., H. S. Shin, and K. Shin, 2013, "Noncore bank liabilities and financial vulnerability," Journal of Money, Credit and Banking, 45(s1), 3-36.

International Monetary Fund, 2010, Global Financial Stability Report, "Global Liquidity Expansion: Effects on 'Receiving' Economies and Policy Response Options,” April (Washington).

, 2011, World Economic Outlook, Chapter 4. International Capital Flows: Reliable or Fickle? April (Washington).

, 2013a, Policy Paper, "Global Liquidity: Credit and Funding Indicators," (Washington).

, 2013b, World Economic Outlook, Chapter 4, "The Yin and Yang of Capital Flow Management: Balancing Capital Inflows with Capital Outflows," October (Washington). 
, 2014a, Policy Paper, “Global Liquidity: Issues for Surveillance,” April (Washington).

, 2014b, Global Financial Stability Report, Chapter 2, "How do Changes in the Investor Base and Financial deepening Affect Emerging Market Economies?," April (Washington).

Jiménez, G., S. Ongena, J.L. Peydró-Alcalde and J. Saurina, 2014. "Hazardous Times for Monetary Policy: What Do Twenty-Three Million Bank Loans Say About the Effects of Monetary Policy on Credit Risk?," Econometrica, forthcoming.

Landau, J.-P., 2013, "Global Liquidity: Public and Private," in Proceedings of the Federal Reserve Bank of Kansas City Economic Symposium at Jackson Hole.

McGuire, P., and N. Tarashev, 2008, "Bank Health and Lending to Emerging Markets," BIS Quarterly Review, pp. 67-80, December.

Rey, H., 2013, "Dilemma not Trilemma: The global financial cycle and monetary policy independence," in Proceedings of the Federal Reserve Bank of Kansas City Economic Symposium at Jackson Hole.

Shin, H.S., 2012 “Global Banking Glut and Loan Risk Premium” Mundell-Fleming Lecture, IMF Economic Review 60 (2), 155-192.

Turner, Philip, 2014. "The global long-term interest rate, financial risks and policy choices in EMEs,” BIS Working Paper no 441, February. 
Table 1 - Variable Definitions and Sources

\begin{tabular}{|c|c|c|}
\hline Variables & Definition & Sources \\
\hline \multicolumn{3}{|l|}{ Dependent variables } \\
\hline Log cross-border claims on banks & $\begin{array}{l}\text { Log Changes in BIS Locational Cross-Border Claims on Banks } \\
\text { (exchange rate adjusted) }\end{array}$ & BIS Locational statistics (Table 6) \\
\hline Log cross-border claims on non-banks & $\begin{array}{l}\text { Log Changes in BIS Locational Cross-Border Claims on Banks } \\
\text { (exchange rate adjusted) }\end{array}$ & BIS Locational statistics (Table 6) \\
\hline \multicolumn{3}{|l|}{ Global drivers } \\
\hline Real GDP Growth & Growth rate of real GDP & WEO \\
\hline Inflation & Inflation & IFTSTSUB and GDS \\
\hline Interest rate Differential & Difference between domestic rate and Fed funds rate & IFTSTSUB \\
\hline Exchange rate flexibility & Ranges from 1-4, with higher values indicating more flexibility. & Ilzetzki, Reinhart and Rogoff (2008) \\
\hline Capital controls & $\begin{array}{l}\text { Higher values of the index represent more restrictions. } \\
\text { The average of the following four indices: bureaucracy quality; }\end{array}$ & Quinn (2011) \\
\hline Institution quality & $\begin{array}{l}\text { law and order; corruption; investment profile. Higher values } \\
\text { indicate lower quality }\end{array}$ & International Country Risk Guide \\
\hline Capital stringency & $\begin{array}{l}\text { Whether capital requirement reflects certain risk elements and } \\
\text { deducts certain market value losses from capital before } \\
\text { minimum capital adequacy is determined. Higher values } \\
\text { indicate greater stringency. } \\
\text { Whether the supervisory authorities have the authority to take }\end{array}$ & World Bank surveys on bank regulation \\
\hline Supervisory power & $\begin{array}{l}\text { specific actions to prevent and correct problems. Higher values } \\
\text { indicate greater power. }\end{array}$ & World Bank surveys on bank regulation \\
\hline Limits on foreign banks & $\begin{array}{l}\text { Whether foreign banks may own domestic banks and whether } \\
\text { foreign banks may enter a country's banking industry. Higher } \\
\text { values indicate great restriction. }\end{array}$ & World Bank surveys on bank regulation \\
\hline US VIX & CBOE S\&P500 Volatility VIX & Datastream \\
\hline UK VIX & FTSE 100 Volatility Index & Datastream \\
\hline EU VIX & VDAX Volatility Index (new) & Datastream \\
\hline JP VIX & NIKKEI Stock Average Volatility Index & Datastream \\
\hline US TED spread & 3-month TED spread (LIBOR - Treasury bill) & Datastream \\
\hline UK TED spread & 3-month GBP LIBOR spread (LIBOR - Gilt) & Datastream \\
\hline EU TED spread & 3-month Euro LIBOR spread (LIBOR - Govt. AAA bill) 1/ & Datastream \\
\hline JP TED spread & 3-month JPN LIBOR spread (LIBOR - Treasury bill) & Datastream and Haver \\
\hline US real policy rate & Federal Funds Target Rate & Haver \\
\hline UK real policy rate & UK Base Rate (Repo rate) & Haver \\
\hline EU real policy rate & Euro Area Deposit facitlity rate & Haver \\
\hline JP real policy rate & Japan deposit facility rate & Haver \\
\hline US slope of yield crurve & 10 year/3 month US Treasury yield spread & Datastream \\
\hline UK slope of yield curve & 10 year/3 month UK government securities yield spread & Datastream \\
\hline EU slope of yield curve & 10 year/3 month EA AAA Sovereign yield spread 1/ & Datastream \\
\hline JP slople of yield curve & 10 year/3 month Japan Treasury yield spread & Datastream and Haver \\
\hline US growth rate of $\mathrm{M} 2$ & Growth rate of $\mathrm{M} 2$ in national currency & IFTSTSUB \\
\hline UK growth rate of $\mathrm{M} 2$ & Growth rate of $\mathrm{M} 2$ in national currency & IFTSTSUB \\
\hline EU growth rate of $\mathrm{M} 2$ & Growth rate of $\mathrm{M} 2$ in national currency & IFTSTSUB \\
\hline JP growth rate of $\mathrm{M} 2$ & Growth rate of $\mathrm{M} 2$ in national currency & IFTSTSUB \\
\hline US bank leverage & (Equity+Total Liabilities)/Equity & US Flow of Funds \\
\hline UK bank leverage & Total Assets/Equity & Bank of England \\
\hline EU bank leverage & Total Assets/Equity & European Central Bank \\
\hline JP bank leverage & Total Assets/Equity & Bank of Japan \\
\hline US growth rate of real credit & Real private credit & IFTSTSUB and MBRF2 \\
\hline UK growth rate of real credit & Real private credit & IFTSTSUB \\
\hline EU growth rate of real credit & Real private credit & IFTSTSUB \\
\hline JP growth rate of real credit & Real private credit & IFTSTSUB and MBRF2 \\
\hline
\end{tabular}

Note: 1/ Data on Euro Government AAA 3-month bill is available since 2007, so the period 2001-2006 is based on the 3 month French treasury bill rate.

\section{CInternational Monetary Fund. Not for Redistribution}


Table 2: Summary Statistics, Correlations over Full Sample (1990Q1-2012Q4) and Regional Distribution Panel A - Summary Statistics

Variable

Log cross-border claims on banks

Log cross-border claims on non-bant GDP Growth (lag)

Inflation (lag)

Change in Interest Rate Differential

CBOE VIX

US TED Spread

US Bank Leverage

Growth of Real US Credit

Real US Federal Fund Rate

US Slope of Yield Curve

S4 Countries M2

Panel B - Correlation Matrix

Obs

5448

5420

5446

5447

5448

5448

5448

5448

5448

5448

5448

5448

$$
\text { Mean }
$$

$$
1.61
$$

1.44

3.87

5.06

$-0.26$

21.21

0.53

19.11

2.31

0.62

1.84

6.06
Median Std. Dev.

1.30
1.12
3.79
3.29
-0.04
20.18
0.45
19.80
3.58
0.50
1.91
5.96

10.43

$$
6.88
$$$$
4.78
$$$$
6.18
$$$$
4.74
$$$$
9.00
$$$$
0.41
$$$$
4.91
$$$$
4.29
$$$$
2.05
$$$$
1.15
$$$$
5.80
$$

$P 25$
-3.08
-1.96
1.58
1.83
-1.40
14.91
0.23
14.60
0.31
-1.05
0.88
1.62

P75

$\begin{array}{cc}\text { Min } & \text { Max } \\ -42.62 & 43.83 \\ -22.21 & 27.15 \\ -20.34 & 24.50 \\ -2.80 & 70.59 \\ -31.65 & 40.13 \\ 11.11 & 68.51 \\ 0.12 & 2.15 \\ 8.91 & 30.62 \\ -8.52 & 7.74 \\ -3.67 & 4.04 \\ -0.48 & 3.63 \\ -7.02 & 18.63\end{array}$

\section{GDP}

Growth

Inflation
Change in CBOE VIX US TED Interest Rate

Spread (lag)

1.00

0.01

0.02

$-0.08$

0.11

0.17

0.09

0.08

$-0.17$

0.00

1.00
-0.15
0.04
0.09
-0.05
-0.06
0.07
-0.02
0.01

1.00

0.04

0.09

$-0.05$

$-0.06$

$-0.02$

0.01

$$
\begin{aligned}
& 1.00 \\
& 0.16 \\
& 0.12 \\
& 0.01 \\
& -0.12 \\
& -0.05 \\
& 0.05 \\
& 0.05
\end{aligned}
$$

\begin{tabular}{|c|c|c|c|}
\hline Asia & Europe & Western Hemisphere & Other regions \\
\hline Australia & Austria 1/ & Argentina & Algeria \\
\hline China & Belgium 1/ & Bolivia & Bahrain, Kingdom of \\
\hline Hong Kong & Bulgaria & Brazil & Côte d'Ivoire \\
\hline India & Croatia & Canada & Ghana \\
\hline Indonesia & Cyprus 1/ & Chile & Israel \\
\hline Japan 1/ & Czech Republic & Colombia & Jordan \\
\hline Malaysia & Denmark & Guatemala & Kuwait \\
\hline New Zealand & Estonia 1/ & Jamaica & Libya \\
\hline Pakistan & Finland 1/ & Mexico & Mauritius \\
\hline Philippines & France 1/ & Panama & Morocco \\
\hline Singapore & Germany 1/ & Paraguay & Oman \\
\hline South Korea & Greece 1/ & Peru & Qatar \\
\hline Sri Lanka & Hungary & United States 1/ & Saudi Arabia \\
\hline \multirow[t]{18}{*}{ Thailand } & Iceland & Venezuela, Rep. Bol. & Senegal \\
\hline & Ireland 1/ & & South Africa \\
\hline & Italy $1 /$ & & Tunisia \\
\hline & Latvia & & \\
\hline & Lithuania & & \\
\hline & Luxembourg 1/ & & \\
\hline & Norway & & \\
\hline & Poland & & \\
\hline & Portugal 1/ & & \\
\hline & Romania & & \\
\hline & Russia & & \\
\hline & Slovak Republic 1/ & & \\
\hline & Slovenia 1/ & & \\
\hline & Sweden & & \\
\hline & Switzerland & & \\
\hline & Turkey & & \\
\hline & Ukraine & & \\
\hline & United Kingdom 1/ & & \\
\hline
\end{tabular}$$
-0.12
$$$$
-0.05
$$

1.00
0.40
-0.23
-0.17
-0.09
0.18
-0.05

1.00
0.21
0.13
0.25
-0.30
0.14
US Bank Growth of Real US US Slope S4 Leverage Real US Federal of Yield Countries Credit Fund Rate Curve M2

Panel C - Regional distribution of countries included in the Sample ( 1 / if S4 country member)

\section{CInternational Monetary Fund. Not for Redistribution}


Table 3 - Summary Statistics and Correlations over the Period 2001Q1-2012Q4 for Individual S4 Variables

Panel A - Summary Statistics Variable

Growth of claims on banks Growth of claims on non-banks GDP Growth (lag)

Inflation (lag)

Change in Interest rate Differential S4 Countries M2

US VIX

UK VIX

EU VIX

JP VIX

US TED spread

UK TED spread

EU TED spread

JP TED spread

US real policy rate

UK real policy rate

EU real policy rate

JP real policy rate

US slope of yield crurve

UK slope of yield curve

EU slope of yield curve

JP slople of yield curve

US growth rate of $\mathrm{M} 2$

UK growth rate of $\mathrm{M} 2$

EU growth rate of $\mathrm{M} 2$

$J P$ growth rate of $\mathrm{M} 2$

US Dealer bank leverage

UK bank leverage

EU bank leverage

JP bank leverage

US growth rate of real credit

UK growth rate of real credit

EU growth rate of real credit

JP growth rate of real credit

$\begin{array}{ccccc}\text { Obs } & \text { Mean } & \text { Std. Dev. } & \text { Min } & \text { Max } \\ 2503 & 1.88 & 12.35 & -42.62 & 43.83 \\ 2499 & 1.84 & 8.35 & -22.21 & 27.15 \\ 2501 & 4.48 & 4.99 & -20.34 & 24.50 \\ 2502 & 5.17 & 5.47 & -2.80 & 70.33 \\ 2503 & -0.01 & 4.24 & -31.65 & 40.13 \\ 2503 & 6.96 & 5.42 & -2.99 & 18.02 \\ 2503 & 22.22 & 10.38 & 11.24 & 68.51 \\ 2503 & 21.13 & 8.40 & 10.12 & 49.57 \\ 2503 & 25.36 & 9.75 & 12.70 & 57.94 \\ 2503 & 26.26 & 9.07 & 15.48 & 65.49 \\ 2503 & 0.48 & 0.48 & 0.12 & 2.15 \\ 2503 & 0.37 & 0.36 & 0.03 & 1.73 \\ 2503 & 0.35 & 0.38 & -0.02 & 1.80 \\ 2503 & 0.13 & 0.13 & -0.03 & 0.59 \\ 2503 & -0.47 & 1.71 & -3.63 & 3.32 \\ 2503 & 0.75 & 2.72 & -4.28 & 4.90 \\ 2503 & -0.71 & 1.05 & -2.54 & 1.59 \\ 2503 & 0.53 & 0.68 & -1.40 & 2.53 \\ 2503 & 2.08 & 1.14 & -0.32 & 3.59 \\ 2503 & 1.07 & 1.31 & -0.63 & 3.56 \\ 2503 & 2.00 & 1.15 & 0.25 & 4.06 \\ 2503 & 1.16 & 0.26 & 0.46 & 1.56 \\ 2503 & 6.35 & 2.26 & 1.27 & 10.54 \\ 2503 & 7.86 & 5.48 & -3.66 & 17.04 \\ 2503 & 6.41 & 2.80 & 1.43 & 10.51 \\ 2503 & 2.19 & 0.73 & 0.47 & 3.56 \\ 2503 & 20.00 & 5.50 & 12.43 & 30.62 \\ 2503 & 15.39 & 2.00 & 11.81 & 19.52 \\ 2503 & 16.99 & 1.15 & 13.95 & 18.08 \\ 2503 & 23.96 & 2.19 & 20.97 & 28.79 \\ 2503 & 2.47 & 4.10 & -8.52 & 7.71 \\ 2503 & 4.40 & 7.16 & -10.86 & 13.32 \\ 2503 & 3.59 & 3.92 & -4.05 & 9.81 \\ 2503 & -0.96 & 2.77 & -8.34 & 4.27 \\ & & & & \end{array}$

Panel B - Correlation Matrix (selected cases)

US VIX

UK VIX

EUVIX

JP VIX

US TED spread

UK TED spread

EU TED spread

JP TED spread

US real policy rate

UK real policy rate

EU real policy rate

JP real policy rate

US slope of yield crurve

UK slope of yield curve

EU slope of yield curve

JP slople of yield curve

US growth rate of $\mathrm{M} 2$

UK growth rate of $\mathrm{M} 2$

EU growth rate of $\mathrm{M} 2$

JP growth rate of $\mathrm{M} 2$

US Dealer bank leverage

UK bank leverage

EU bank leverage

JP bank leverage

US growth rate of real credit

UK growth rate of real credit

EU growth rate of real credit

JP growth rate of real credit
1.00

$0.94 \quad 1.00$

$\begin{array}{lll}0.87 & 0.93 & 1.00\end{array}$

$\begin{array}{llll}0.89 & 0.86 & 0.78 & 1.00\end{array}$

1.00

$0.84 \quad 1.00$

$\begin{array}{lll}0.72 & 0.89 & 1.00\end{array}$

$\begin{array}{llll}0.83 & 0.87 & 0.75 & 1.00\end{array}$

1.00

$0.58 \quad 1.00$

$\begin{array}{lll}0.78 & 0.58 & 1.00\end{array}$

$\begin{array}{llll}0.27 & -0.16 & 0.22 & 1.00\end{array}$

1.00

$0.71 \quad 1.00$

$\begin{array}{lll}0.65 & 0.92 & 1.00\end{array}$

$\begin{array}{llll}-0.06 & -0.20 & -0.17 & 1.00\end{array}$

1.00

$-0.26 \quad 1.00$

$\begin{array}{lll}0.17 & 0.63 & 1.00\end{array}$

$\begin{array}{llll}0.19 & -0.43 & -0.56 & 1.00\end{array}$

1.00

0.821 .00

$\begin{array}{lll}0.72 & 0.75 & 1.00\end{array}$

$\begin{array}{llll}0.33 & 0.32 & 0.56 & 1.00\end{array}$

1.00

$0.79 \quad 1.00$

$\begin{array}{lll}0.64 & 0.87 & 1.00\end{array}$

$\begin{array}{llll}-0.08 & -0.18 & 0.12 & 1.00\end{array}$ 
Table 4 - Regression Results for Cross-Border Claims to Banks and Non-Banks, for period 1990Q1-2012Q4

Panel A - Dependent Variable: Log Changes in BIS Locational Cross-Border Claims on Banks (in \%)

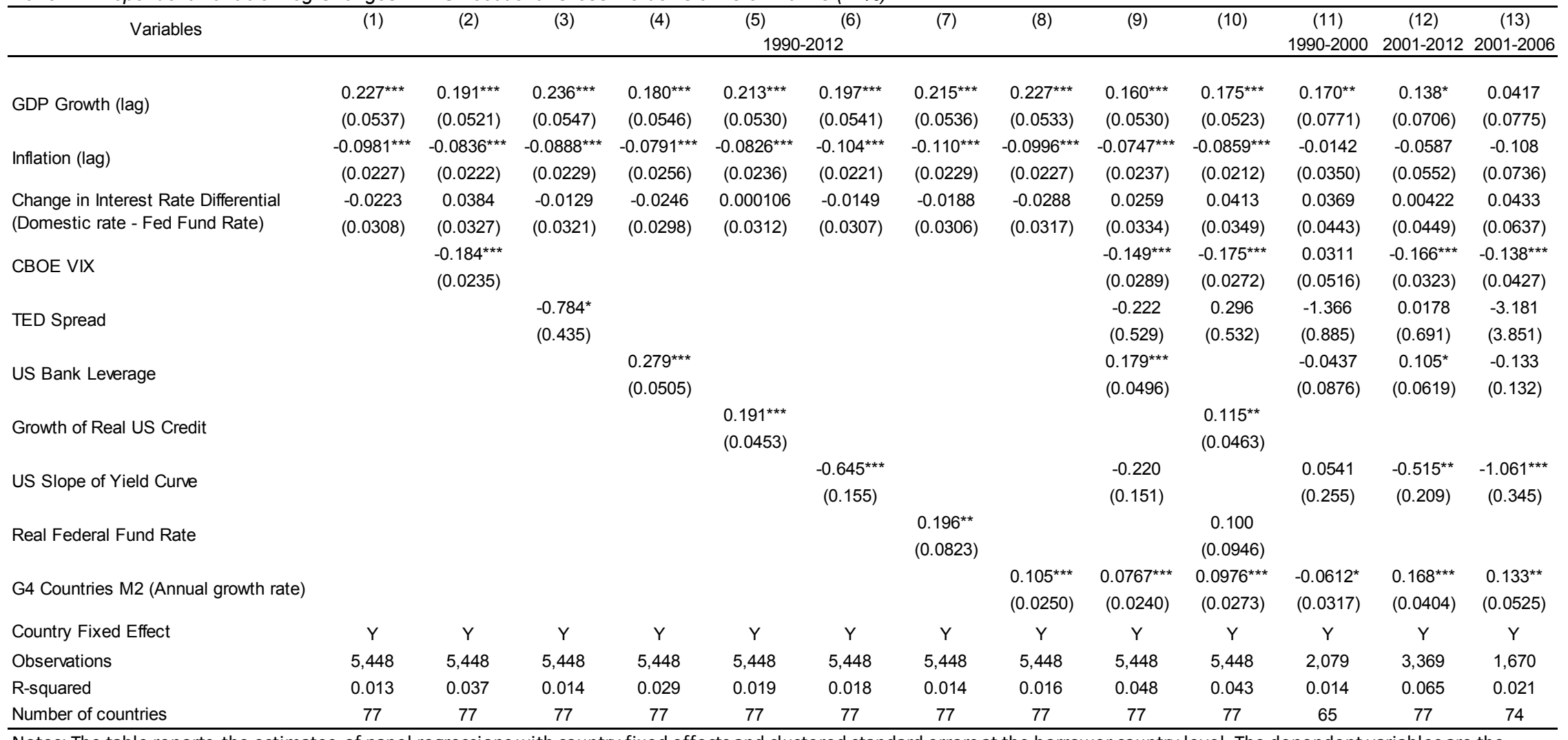

Notes: The table reports the estimates of panel regressions with country fixed effects and clustered standard errors at the borrower country level. The dependent variables are the

change in cross-border claims on banks (Panel A) and non-banks (Panel B). ${ }^{* * *}$ indicate significance at 1 percent, ${ }^{* *}$ at 5 percent, and * at 10 percent, respectively. 
Table 4 Cont. - Regression Results for Cross-Border Claims to Banks and Non-Banks, for period 1990Q1-2012Q4

Panel B - Dependent Variable: Log Changes in BIS Locational Cross-Border Claims on Non-Banks (in \%)

\begin{tabular}{|c|c|c|c|c|c|c|c|c|c|c|c|c|c|}
\hline \multirow{2}{*}{ Variables } & (1) & (2) & (3) & (4) & (5) & (6) & (7) & (8) & (9) & (10) & (11) & (12) & (13) \\
\hline & \multicolumn{10}{|c|}{$1990-2012$} & $1990-2000$ & 2001-2012 & 2001-2006 \\
\hline GDP Growth (lag) & $\begin{array}{l}0.182^{* * *} \\
(0.0298)\end{array}$ & $\begin{array}{l}0.159^{* * *} \\
(0.0284)\end{array}$ & $\begin{array}{l}0.185^{* * *} \\
(0.0302)\end{array}$ & $\begin{array}{l}0.145^{* * *} \\
(0.0249)\end{array}$ & $\begin{array}{l}0.169^{* * *} \\
(0.0272)\end{array}$ & $\begin{array}{l}0.152^{* * *} \\
(0.0283)\end{array}$ & $\begin{array}{l}0.170^{* * *} \\
(0.0295)\end{array}$ & $\begin{array}{l}0.182^{* * *} \\
(0.0295)\end{array}$ & $\begin{array}{l}0.126^{* * *} \\
(0.0250)\end{array}$ & $\begin{array}{l}0.141^{* * *} \\
(0.0267)\end{array}$ & $\begin{array}{l}0.137^{* * *} \\
(0.0296)\end{array}$ & $\begin{array}{l}0.126^{* * *} \\
(0.0387)\end{array}$ & $\begin{array}{l}-0.0454 \\
(0.0536)\end{array}$ \\
\hline Inflation (lag) & $\begin{array}{l}-0.0223 \\
(0.0197)\end{array}$ & $\begin{array}{l}-0.0123 \\
(0.0187)\end{array}$ & $\begin{array}{l}-0.0193 \\
(0.0195)\end{array}$ & $\begin{array}{r}-0.00745 \\
(0.0210)\end{array}$ & $\begin{array}{r}-0.00609 \\
(0.0206)\end{array}$ & $\begin{array}{l}-0.0288 \\
(0.0199)\end{array}$ & $\begin{array}{l}-0.0353^{*} \\
(0.0198)\end{array}$ & $\begin{array}{l}-0.0228 \\
(0.0196)\end{array}$ & $\begin{array}{l}-0.00680 \\
(0.0197)\end{array}$ & $\begin{array}{l}-0.0102 \\
(0.0192)\end{array}$ & $\begin{array}{l}0.00804 \\
(0.0179)\end{array}$ & $\begin{array}{c}0.0245 \\
(0.0365)\end{array}$ & $\begin{array}{l}-0.0401 \\
(0.0364)\end{array}$ \\
\hline $\begin{array}{l}\text { Change in Interest Rate Differential } \\
\text { (Domestic rate - Fed Fund Rate) }\end{array}$ & $\begin{array}{l}-0.0143 \\
(0.0281)\end{array}$ & $\begin{array}{c}0.0241 \\
(0.0270)\end{array}$ & $\begin{array}{l}-0.0113 \\
(0.0284)\end{array}$ & $\begin{array}{l}-0.0160 \\
(0.0270)\end{array}$ & $\begin{array}{l}0.00823 \\
(0.0273)\end{array}$ & $\begin{array}{r}-0.00675 \\
(0.0272)\end{array}$ & $\begin{array}{l}-0.0107 \\
(0.0276)\end{array}$ & $\begin{array}{l}-0.0166 \\
(0.0285)\end{array}$ & $\begin{array}{c}0.0171 \\
(0.0268)\end{array}$ & $\begin{array}{c}0.0330 \\
(0.0272)\end{array}$ & $\begin{array}{c}0.0258 \\
(0.0353)\end{array}$ & $\begin{array}{r}-0.00775 \\
(0.0344)\end{array}$ & $\begin{array}{l}-0.00873 \\
(0.0289)\end{array}$ \\
\hline CBOE VIX & & $\begin{array}{l}-0.118^{* * *} \\
(0.0142)\end{array}$ & & & & & & & $\begin{array}{c}-0.0897^{\star * *} \\
(0.0160)\end{array}$ & $\begin{array}{l}-0.113^{* * *} \\
(0.0156)\end{array}$ & $\begin{array}{l}-0.0246 \\
(0.0296)\end{array}$ & $\begin{array}{l}-0.115^{\star \star *} \\
(0.0210)\end{array}$ & $\begin{array}{c}-0.151^{* * *} \\
(0.0295)\end{array}$ \\
\hline TED Spread & & & $\begin{array}{l}-0.248 \\
(0.279)\end{array}$ & & & & & & $\begin{array}{l}-0.0969 \\
(0.329)\end{array}$ & $\begin{array}{c}0.403 \\
(0.328)\end{array}$ & $\begin{array}{l}-0.198 \\
(0.610)\end{array}$ & $\begin{array}{c}0.377 \\
(0.413)\end{array}$ & $\begin{array}{l}-3.269 \\
(2.623)\end{array}$ \\
\hline US Bank Leverage & & & & $\begin{array}{l}0.223^{* * *} \\
(0.0310)\end{array}$ & & & & & $\begin{array}{l}0.150^{* * *} \\
(0.0316)\end{array}$ & & $\begin{array}{c}0.0789 \\
(0.0564)\end{array}$ & $\begin{array}{l}0.103^{* *} \\
(0.0453)\end{array}$ & $\begin{array}{c}0.0417 \\
(0.0594)\end{array}$ \\
\hline Growth of Real US Credit & & & & & $\begin{array}{l}0.195^{\star * *} \\
(0.0292)\end{array}$ & & & & & $\begin{array}{l}0.141^{* * *} \\
(0.0292)\end{array}$ & & & \\
\hline US Slope of Yield Curve & & & & & & $\begin{array}{c}-0.669^{* * *} \\
(0.0918)\end{array}$ & & & $\begin{array}{l}-0.303^{* * *} \\
(0.0986)\end{array}$ & & $\begin{array}{l}-0.185 \\
(0.128)\end{array}$ & $\begin{array}{c}-0.402^{* *} \\
(0.198)\end{array}$ & $\begin{array}{c}-0.919^{* * *} \\
(0.334)\end{array}$ \\
\hline Real Federal Fund Rate & & & & & & & $\begin{array}{l}0.219^{\star * *} \\
(0.0547)\end{array}$ & & & $\begin{array}{c}0.0660 \\
(0.0630)\end{array}$ & & & \\
\hline G4 Countries M2 (Annual growth rate) & & & & & & & & $\begin{array}{l}0.0382^{* *} \\
(0.0169)\end{array}$ & $\begin{array}{c}0.0211 \\
(0.0153)\end{array}$ & $\begin{array}{l}0.0331^{*} \\
(0.0172)\end{array}$ & $\begin{array}{r}-0.00169 \\
(0.0259)\end{array}$ & $\begin{array}{c}0.0137 \\
(0.0295)\end{array}$ & $\begin{array}{l}0.00497 \\
(0.0388)\end{array}$ \\
\hline Country Fixed Effect & Y & Y & Y & Y & Y & Y & Y & Y & Y & Y & Y & Y & Y \\
\hline Observations & 5,420 & 5,420 & 5,420 & 5,420 & 5,420 & 5,420 & 5,420 & 5,420 & 5,420 & 5,420 & 2,055 & 3,365 & 1,666 \\
\hline R-squared & 0.015 & 0.039 & 0.015 & 0.040 & 0.029 & 0.027 & 0.019 & 0.016 & 0.056 & 0.050 & 0.019 & 0.070 & 0.041 \\
\hline Number of countries & 77 & 77 & 77 & 77 & 77 & 77 & 77 & 77 & 77 & 77 & 65 & 77 & 74 \\
\hline
\end{tabular}

Notes: The table reports the estimates of panel regressions with country fixed effects and clustered standard errors at the borrower country level. The dependent variables are the

change in cross-border claims on banks (Panel A) and non-banks (Panel B). ${ }^{* * *}$ indicate significance at 1 percent, ${ }^{* *}$ at 5 percent, and ${ }^{*}$ at 10 percent, respectively. 
Table 5 - Regression Results for Cross-Border Claims to Banks and Non-Banks, Individual S4 variables Panel A - Dependent Variable: Log Changes in BIS Locational Cross-Border Claims on Banks (in \%)

\begin{tabular}{|c|c|c|c|c|c|c|c|c|}
\hline \multicolumn{2}{|c|}{ S4 Economy } & VIX & TED & \multirow{2}{*}{$\begin{array}{c}\text { Bank } \\
\text { Leverage }\end{array}$} & \multirow{2}{*}{$\begin{array}{c}\text { Real Credit } \\
\text { Growth }\end{array}$} & \multirow{2}{*}{$\begin{array}{c}\begin{array}{c}\text { Real Policy } \\
\text { Rate }\end{array} \\
\text { 0.446*** }\end{array}$} & \multirow{2}{*}{$\begin{array}{c}\begin{array}{c}\text { Slope of } \\
\text { yield curve }\end{array} \\
-1.309 * * *\end{array}$} & \multirow{2}{*}{$\begin{array}{c}\text { M2 growth } \\
\text { (national } \\
\text { currency) }\end{array}$} \\
\hline & Coefficient & $-0.251 * * *$ & -0.433 & & & & & \\
\hline US & Standard error & $(0.0294)$ & $(0.668)$ & $(0.0652)$ & (0.0791) & $(0.138)$ & $(0.242)$ & (0.139) \\
\hline & $\mathrm{R} 2$ & 0.051 & 0.010 & 0.035 & 0.019 & 0.014 & 0.024 & 0.032 \\
\hline \multirow{3}{*}{ UK } & Coefficient & $-0.258 * * *$ & $-4.455^{* * *}$ & $0.930 * * *$ & $0.127^{* *}$ & $0.454^{* * *}$ & $-1.214^{* * *}$ & $0.110^{* *}$ \\
\hline & Standard error & $(0.0337)$ & $(0.861)$ & (0.159) & $(0.0481)$ & $(0.129)$ & $(0.294)$ & (0.0458) \\
\hline & $\mathrm{R} 2$ & 0.039 & 0.025 & 0.031 & 0.015 & 0.019 & 0.025 & 0.012 \\
\hline \multirow{3}{*}{ EU } & Coefficient & $-0.243^{* * *}$ & $-3.213^{* * *}$ & $0.624^{* *}$ & $0.393^{* * *}$ & 0.0815 & $-1.338 * * *$ & $0.401^{* * *}$ \\
\hline & Standard error & $(0.0291)$ & $(0.764)$ & $(0.285)$ & $(0.0864)$ & $(0.224)$ & $(0.303)$ & $(0.130)$ \\
\hline & $\mathrm{R} 2$ & 0.046 & 0.019 & 0.013 & 0.025 & 0.010 & 0.025 & 0.017 \\
\hline \multirow{3}{*}{$J P$} & Coefficient & $-0.271 * * *$ & $-8.463 * * *$ & 0.0617 & 0.0548 & -0.250 & $1.941 * *$ & $-1.580 * * *$ \\
\hline & Standard error & $(0.0315)$ & $(2.021)$ & $(0.123)$ & $(0.0916)$ & $(0.435)$ & $(0.878)$ & $(0.348)$ \\
\hline & $\mathrm{R} 2$ & 0.045 & 0.017 & 0.010 & 0.010 & 0.010 & 0.012 & 0.018 \\
\hline
\end{tabular}

Panel B - Dependent Variable: Log Changes in BIS Locational Cross-Border Claims on Non-Banks (in \%)

\begin{tabular}{|c|c|c|c|c|c|c|c|c|}
\hline \multicolumn{2}{|c|}{ S4 Economy } & VIX & TED & $\begin{array}{c}\text { Bank } \\
\text { Leverage }\end{array}$ & $\begin{array}{l}\text { Real Credit } \\
\text { Growth }\end{array}$ & $\begin{array}{c}\text { Real Policy } \\
\text { Rate }\end{array}$ & $\begin{array}{c}\text { Slope of } \\
\text { yield curve }\end{array}$ & $\begin{array}{l}\text { M2 growth } \\
\text { (national } \\
\text { currency) }\end{array}$ \\
\hline & Coefficient & $-0.163 * * *$ & 0.113 & $0.264^{* * *}$ & $0.288 * * *$ & $0.636 * * *$ & $-1.234 * * *$ & $-0.523 * * *$ \\
\hline \multirow[t]{3}{*}{ US } & Standard error & $(0.0184)$ & $(0.377)$ & $(0.0438)$ & $(0.0580)$ & $(0.108)$ & $(0.170)$ & $(0.0832)$ \\
\hline & $\mathrm{R} 2$ & 0.052 & 0.013 & 0.043 & 0.033 & 0.031 & 0.041 & 0.031 \\
\hline & Coefficient & $-0.163 * * *$ & $-2.617^{* * *}$ & $0.734^{* * *}$ & $0.119 * * *$ & $0.382^{* * *}$ & $-0.935 * * *$ & $0.146^{* * *}$ \\
\hline \multirow[t]{3}{*}{ UK } & Standard error & $(0.0203)$ & $(0.526)$ & (0.109) & $(0.0330)$ & $(0.0889)$ & $(0.183)$ & $(0.0350)$ \\
\hline & $\mathrm{R} 2$ & 0.039 & 0.025 & 0.043 & 0.024 & 0.029 & 0.034 & 0.023 \\
\hline & Coefficient & $-0.162^{* * *}$ & $-2.392^{* * *}$ & $0.623^{* * *}$ & $0.337^{* * *}$ & $0.381^{* *}$ & $-1.049 * * *$ & $0.361^{* * *}$ \\
\hline \multirow[t]{3}{*}{ EU } & Standard error & $(0.0174)$ & $(0.498)$ & $(0.200)$ & $(0.0569)$ & $(0.157)$ & (0.197) & $(0.0859)$ \\
\hline & $\mathrm{R} 2$ & 0.049 & 0.024 & 0.021 & 0.037 & 0.016 & 0.034 & 0.027 \\
\hline & Coefficient & $-0.157^{* * *}$ & $-3.677^{* * *}$ & 0.0957 & $0.253^{* * *}$ & 0.114 & $2.172 * * *$ & $-1.358 * * *$ \\
\hline \multirow[t]{2}{*}{$J P$} & Standard error & $(0.0198)$ & (1.199) & $(0.0878)$ & $(0.0580)$ & $(0.270)$ & $(0.791)$ & $(0.250)$ \\
\hline & $\mathrm{R} 2$ & 0.040 & 0.017 & 0.014 & 0.021 & 0.014 & 0.018 & 0.027 \\
\hline
\end{tabular}

Notes: The table reports the estimates of panel regressions with country fixed effects and clustered standard errors at the borrower country level. Only non-S4 countries are included in the estimations, which reduces the sample to 58 countries (2,503 observations). The dependent variables are the change in cross-border claims on banks and non banks. The variables reported in the table were introduced individually (not all simultaneously). All regressions also include lag GDP growth, lag CPI inflation, and change in interest rate differentials, but they are not reported. *** indicate significance at 1 percent, ${ }^{* *}$ at 5 percent, and ${ }^{*}$ at 10 percent, respectively. 
Table 6 - Regression Results for Cross-Border Claims to Banks and Non-Banks, Individual S4 Variables by Region

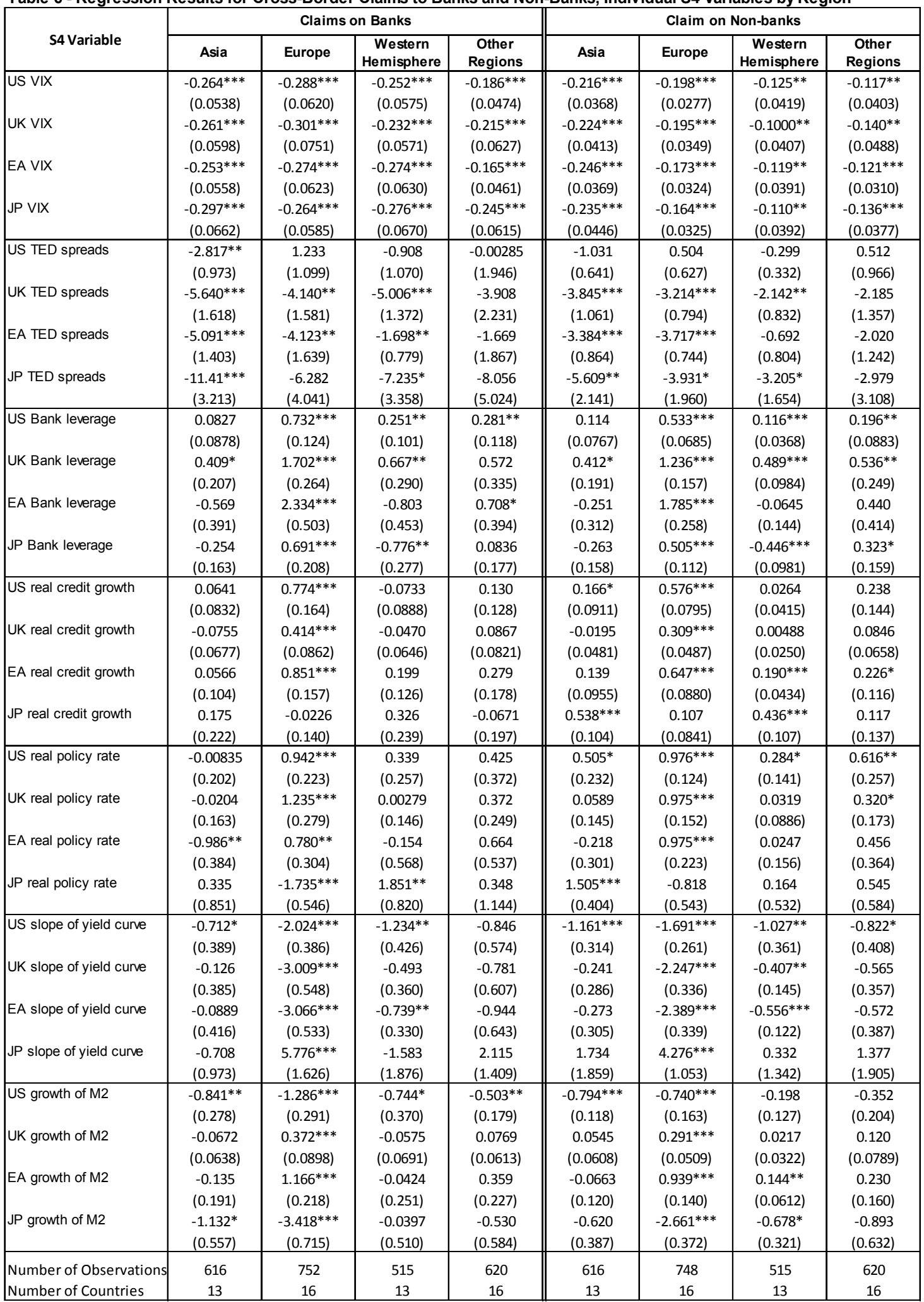

Notes: The table reports the estimates of panel regressions with country fixed effects and clustered standard errors at the borrower country level. Each region is estimated separately, with only non-S4 countries being included. The dependent variables are the change in cross-border claims on banks and non-banks. The variables reported in each row of the table were introduced individually (not all simultaneously). All regressions also include lag GDP growth, lag CPI inflation, and change in interest rate differentials, but they are not reported. ${ }^{* * *}$ indicate significance at 1 percent, ** at 5 percent, and $*$ at 10 percent, respectively. 
Table 7 - Interaction Effects of Country Characteritics with Global Liquidity Variables

Panel A - Dependent Variable: Log Changes in BIS Locational Cross-Border Claims on Banks (in \%)

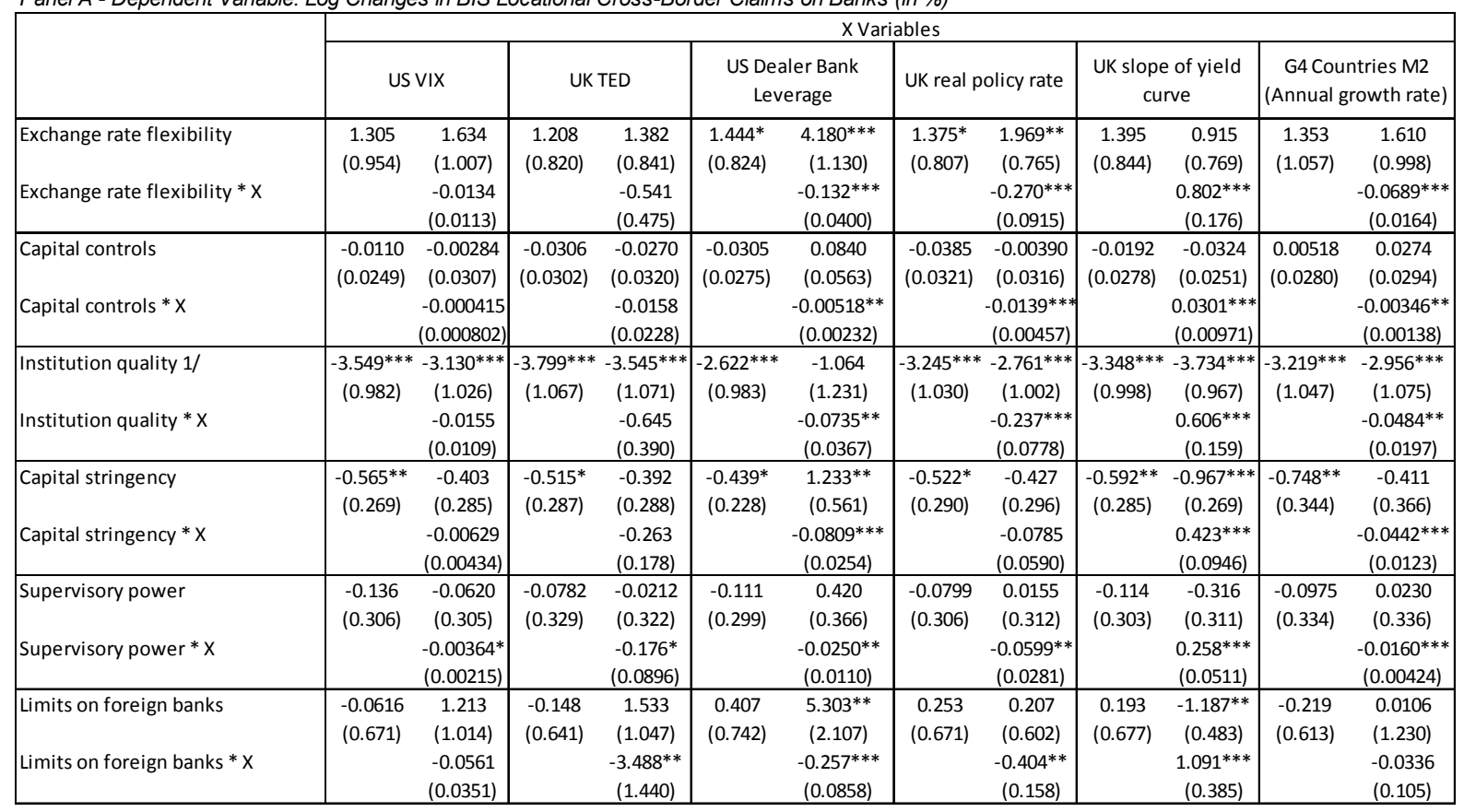

Panel B - Dependent Variable: Log Changes in BIS Locational Cross-Border Claims on Non-Banks (in \%)

\begin{tabular}{|c|c|c|c|c|c|c|c|c|c|c|c|c|}
\hline \multirow[b]{3}{*}{ Exchange rate flexibility } & \multicolumn{12}{|c|}{$\mathrm{X}$ Variables } \\
\hline & \multicolumn{2}{|c|}{ US VIX } & \multicolumn{2}{|c|}{ UK TED } & \multicolumn{2}{|c|}{$\begin{array}{l}\text { US Dealer Bank } \\
\text { Leverage }\end{array}$} & \multicolumn{2}{|c|}{ US real policy rate } & \multicolumn{2}{|c|}{$\begin{array}{l}\text { US slope of yield } \\
\text { curve }\end{array}$} & \multicolumn{2}{|c|}{$\begin{array}{c}\text { G4 Countries M2 } \\
\text { (Annual growth rate) }\end{array}$} \\
\hline & $\begin{array}{l}-0.874 \\
(0.534)\end{array}$ & $\begin{array}{l}-0.710 \\
(0.537)\end{array}$ & $\begin{array}{l}-0.875 \\
(0.864)\end{array}$ & $\begin{array}{l}-0.854 \\
(0.857)\end{array}$ & $\begin{array}{l}-0.756 \\
(0.807)\end{array}$ & $\begin{array}{c}1.297 \\
(0.948)\end{array}$ & $\begin{array}{l}-0.908 \\
(0.730)\end{array}$ & $\begin{array}{l}-0.966 \\
(0.784)\end{array}$ & $\begin{array}{l}-0.903^{*} \\
(0.499)\end{array}$ & $\begin{array}{l}-0.931^{*} \\
(0.537)\end{array}$ & $\begin{array}{l}-0.883 \\
(0.599)\end{array}$ & $\begin{array}{r}-0.649 \\
(0.671)\end{array}$ \\
\hline Exchange rate flexibility $* x$ & & $\begin{array}{l}-0.00676 \\
(0.00623) \\
\end{array}$ & & $\begin{array}{r}-0.0649 \\
(0.190) \\
\end{array}$ & & $\begin{array}{c}-0.0988 * * * \\
(0.0268) \\
\end{array}$ & & $\begin{array}{r}0.195^{* * *} \\
(0.0563)\end{array}$ & & $\begin{array}{r}0.0159 \\
(0.0846) \\
\end{array}$ & & $\begin{array}{c}-0.0517^{* * *} \\
(0.0135) \\
\end{array}$ \\
\hline $\begin{array}{l}\text { Capital controls } \\
\text { Capital controls *X }\end{array}$ & $\begin{array}{r}-0.0397 \\
(0.0245)\end{array}$ & $\begin{array}{c}-0.0369 \\
(0.0267) \\
-0.000143 \\
(0.000496)\end{array}$ & \begin{tabular}{|c}
$-0.0503^{*}$ \\
$(0.0275)$
\end{tabular} & $\begin{array}{c}-0.0507^{*} \\
(0.0277) \\
0.00216 \\
(0.0144) \\
\end{array}$ & $\begin{array}{c}-0.0544 * * \\
(0.0259)\end{array}$ & $\begin{array}{c}0.0331 \\
(0.0357) \\
-0.00395 * * * \\
(0.00131) \\
\end{array}$ & $\begin{array}{r}-0.0382 \\
(0.0259)\end{array}$ & $\begin{array}{c}-0.0385 \\
(0.0261) \\
0.00177 \\
(0.00356)\end{array}$ & $\begin{array}{l}-0.0225 \\
(0.0249)\end{array}$ & $\begin{array}{c}-0.0334 \\
(0.0274) \\
0.00606 \\
(0.00510)\end{array}$ & $\begin{array}{l}-0.0258 \\
(0.0268)\end{array}$ & $\begin{array}{c}-0.0152 \\
(0.0269) \\
-0.00166^{*} \\
(0.000892)\end{array}$ \\
\hline $\begin{array}{l}\text { Institution quality } 1 / \\
\text { Institution quality } * x\end{array}$ & $\begin{array}{c}-3.007 * * * \\
(0.506)\end{array}$ & $\begin{array}{c}-2.901 * * * \\
(0.472) \\
-0.00392 \\
(0.00621)\end{array}$ & $\begin{array}{c}-3.174 * * * \\
(0.553)\end{array}$ & $\begin{array}{c}-3.233^{* * *} \\
(0.536) \\
0.151 \\
(0.199) \\
\end{array}$ & $\begin{array}{c}-2.371 * * * \\
(0.477)\end{array}$ & $\begin{array}{c}-1.330^{*} \\
(0.723) \\
-0.0491^{* *} \\
(0.0220) \\
\end{array}$ & $\begin{array}{c}-2.924^{* * *} \\
(0.503)\end{array}$ & $\begin{array}{c}-2.955^{* * *} \\
(0.499) \\
0.117^{* *} \\
(0.0501)\end{array}$ & $\begin{array}{c}-3.147 * * * \\
(0.506)\end{array}$ & $\begin{array}{c}-3.141^{* * *} \\
(0.496) \\
-0.00397 \\
(0.0705) \\
\end{array}$ & $\begin{array}{c}-3.081 * * * \\
(0.534)\end{array}$ & $\begin{array}{c}-2.981^{* * *} \\
(0.549) \\
-0.0182 \\
(0.0136) \\
\end{array}$ \\
\hline Capital stringency & $\begin{array}{c}-0.356 \\
(0.268)\end{array}$ & $\begin{array}{l}-0.377 \\
(0.283)\end{array}$ & $\begin{array}{l}-0.369 \\
(0.292)\end{array}$ & $\begin{array}{l}-0.416 \\
(0.293)\end{array}$ & $\begin{array}{l}-0.245 \\
(0.236)\end{array}$ & $\begin{array}{l}1.020 * * \\
(0.490)\end{array}$ & $\begin{array}{l}-0.388 \\
(0.282)\end{array}$ & $\begin{array}{l}-0.318 \\
(0.279)\end{array}$ & $\begin{array}{l}-0.419 \\
(0.275)\end{array}$ & $\begin{array}{l}-0.451 \\
(0.303)\end{array}$ & $\begin{array}{l}-0.498 \\
(0.319)\end{array}$ & $\begin{array}{l}-0.324 \\
(0.333)\end{array}$ \\
\hline Capital stringency $* X$ & & $\begin{array}{c}0.000804 \\
(0.00294) \\
\end{array}$ & & $\begin{array}{c}0.101 \\
(0.111) \\
\end{array}$ & & $\begin{array}{c}-0.0612^{* * *} \\
(0.0206) \\
\end{array}$ & & $\begin{array}{c}0.107 * * * \\
(0.0269) \\
\end{array}$ & & $\begin{array}{c}0.0157 \\
(0.0551) \\
\end{array}$ & & $\begin{array}{c}-0.0229 * * \\
(0.00941)\end{array}$ \\
\hline Supervisory power & $\begin{array}{l}0.0847 \\
(0.143)\end{array}$ & $\begin{array}{c}0.135 \\
(0.145)\end{array}$ & $\begin{array}{c}0.120 \\
(0.157)\end{array}$ & $\begin{array}{c}0.125 \\
(0.157)\end{array}$ & $\begin{array}{l}0.0997 \\
(0.142)\end{array}$ & $\begin{array}{c}0.492 * * \\
(0.243)\end{array}$ & $\begin{array}{c}0.104 \\
(0.149)\end{array}$ & $\begin{array}{c}0.115 \\
(0.147)\end{array}$ & $\begin{array}{l}0.0718 \\
(0.146)\end{array}$ & $\begin{array}{c}0.110 \\
(0.151)\end{array}$ & $\begin{array}{c}0.104 \\
(0.164)\end{array}$ & $\begin{array}{c}0.162 \\
(0.171)\end{array}$ \\
\hline Supervisory power ${ }^{*} \mathrm{X}$ & & $\begin{array}{l}-0.00250 \\
(0.00156) \\
\end{array}$ & & $\begin{array}{r}-0.0146 \\
(0.0578) \\
\end{array}$ & & $\begin{array}{l}-0.0185^{* *} \\
(0.00888) \\
\end{array}$ & & $\begin{array}{c}0.0502 * * * \\
(0.0124) \\
\end{array}$ & & $\begin{array}{r}-0.0191 \\
(0.0231) \\
\end{array}$ & & $\begin{array}{l}-0.00769 * \\
(0.00411) \\
\end{array}$ \\
\hline Limits on foreign banks & $\begin{array}{l}-0.724 \\
(0.561)\end{array}$ & $\begin{array}{l}-0.664^{*} \\
(0.371)\end{array}$ & $\begin{array}{l}-0.807 \\
(0.582)\end{array}$ & $\begin{array}{l}-0.723 \\
(0.462)\end{array}$ & $\begin{array}{l}-0.391 \\
(0.571)\end{array}$ & $\begin{array}{c}1.783 \\
(1.415)\end{array}$ & $\begin{array}{l}-0.700 \\
(0.549)\end{array}$ & $\begin{array}{l}-0.802 \\
(0.551)\end{array}$ & $\begin{array}{l}-0.726 \\
(0.551)\end{array}$ & $\begin{array}{c}-1.140^{* * *} \\
(0.419)\end{array}$ & $\begin{array}{l}-0.911 \\
(0.578)\end{array}$ & $\begin{array}{l}-0.731 \\
(0.845)\end{array}$ \\
\hline Limits on foreign banks * $X$ & & $\begin{array}{r}-0.00263 \\
(0.0197) \\
\end{array}$ & & $\begin{array}{l}-0.174 \\
(0.518) \\
\end{array}$ & & $\begin{array}{l}-0.114^{* *} \\
(0.0496) \\
\end{array}$ & & $\begin{array}{c}-0.150 \\
(0.0968) \\
\end{array}$ & & $\begin{array}{c}0.205 \\
(0.175) \\
\end{array}$ & & $\begin{array}{l}-0.0264 \\
(0.0445) \\
\end{array}$ \\
\hline
\end{tabular}

Notes: The table reports the estimates of panel regressions with country fixed effects and clustered standard errors at the borrower country level. The

dependent variables are the change in cross-border claims on banks and non banks. The variables reported in the table were introduced individually (not all simultaneously). All regressions also include lag GDP growth, lag CPI inflation, change in interest rate differentials, and the respective $\mathrm{X}$ variable, but they are not reported. ${ }^{* *}$ indicate significance at 1 percent, ${ }^{* *}$ at 5 percent, and ${ }^{*}$ at 10 percent, respectively. 1/High values indicate lower institutional quality. 
Annex A. Time series charts of the drivers of global liquidity
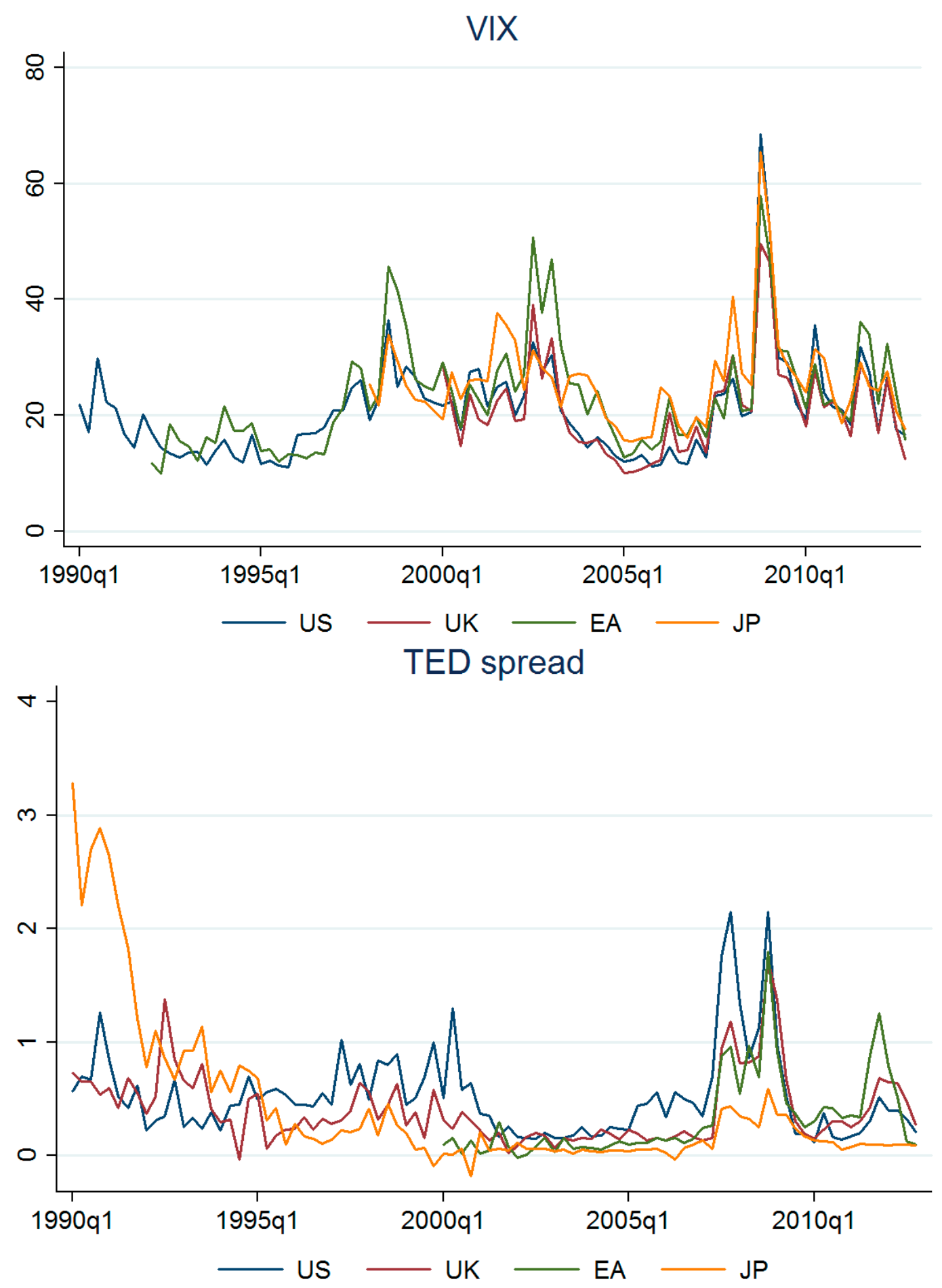

CInternational Monetary Fund. Not for Redistribution 
Bank leverage

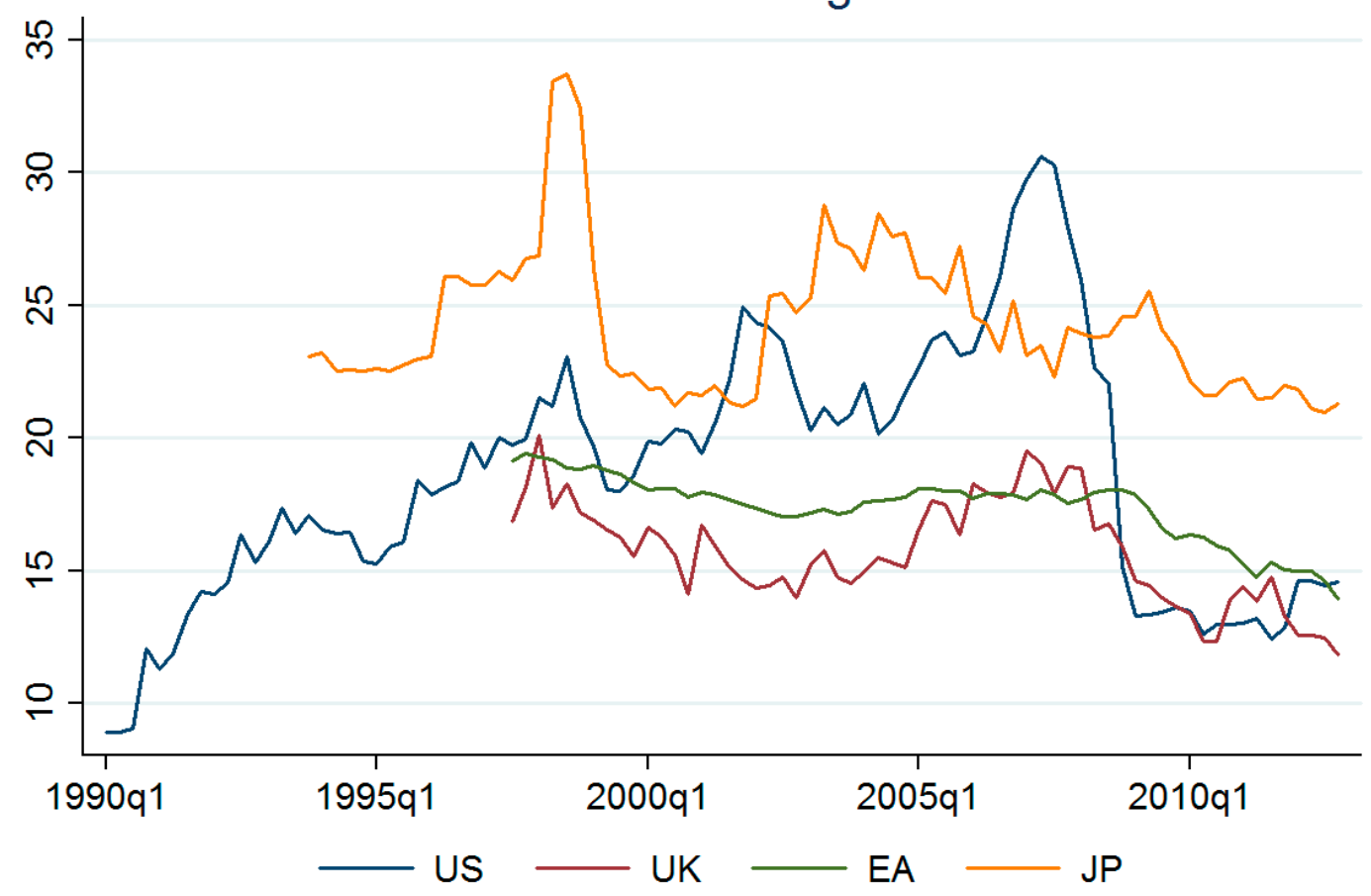

Growth rate of real credit

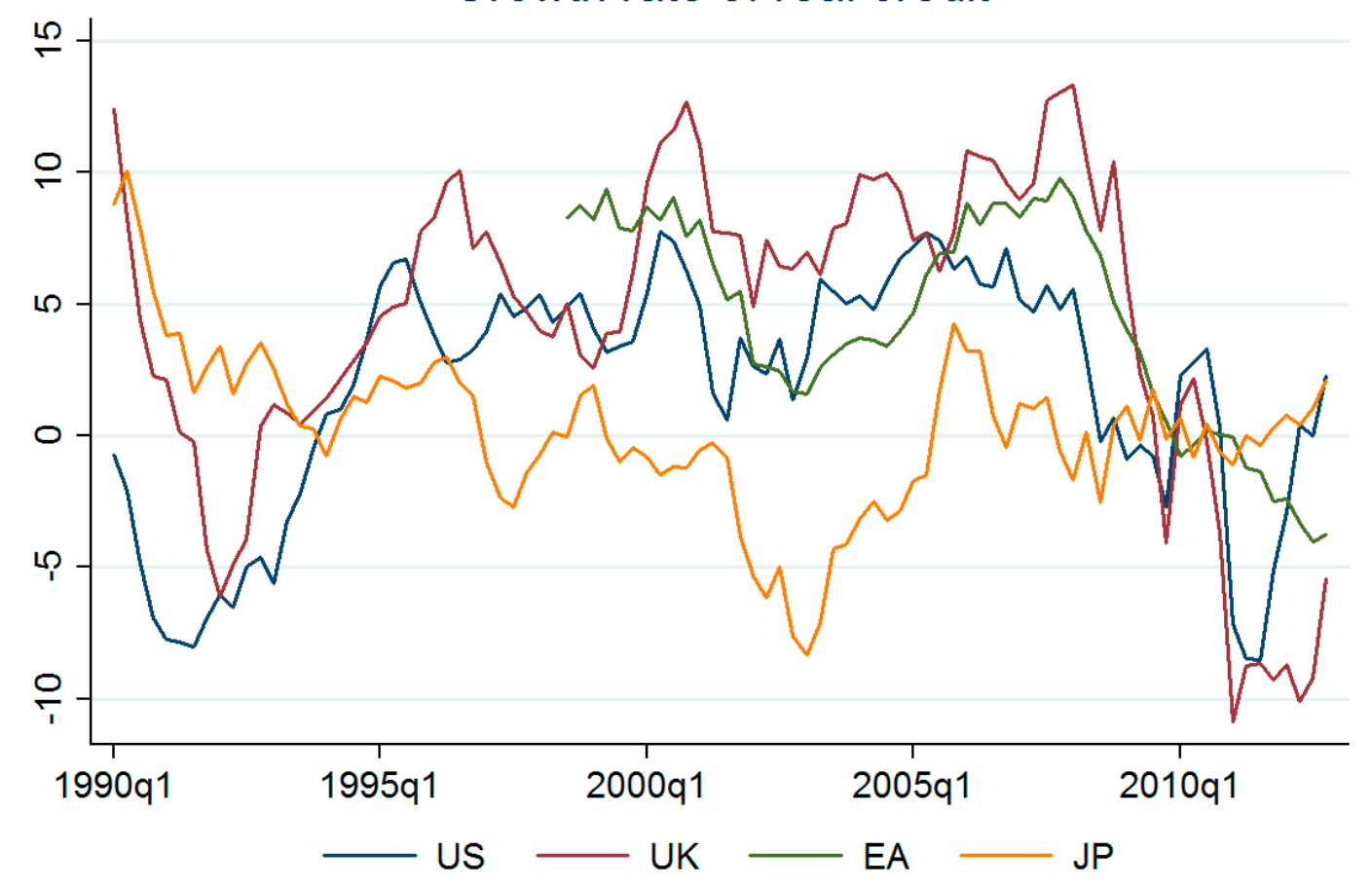



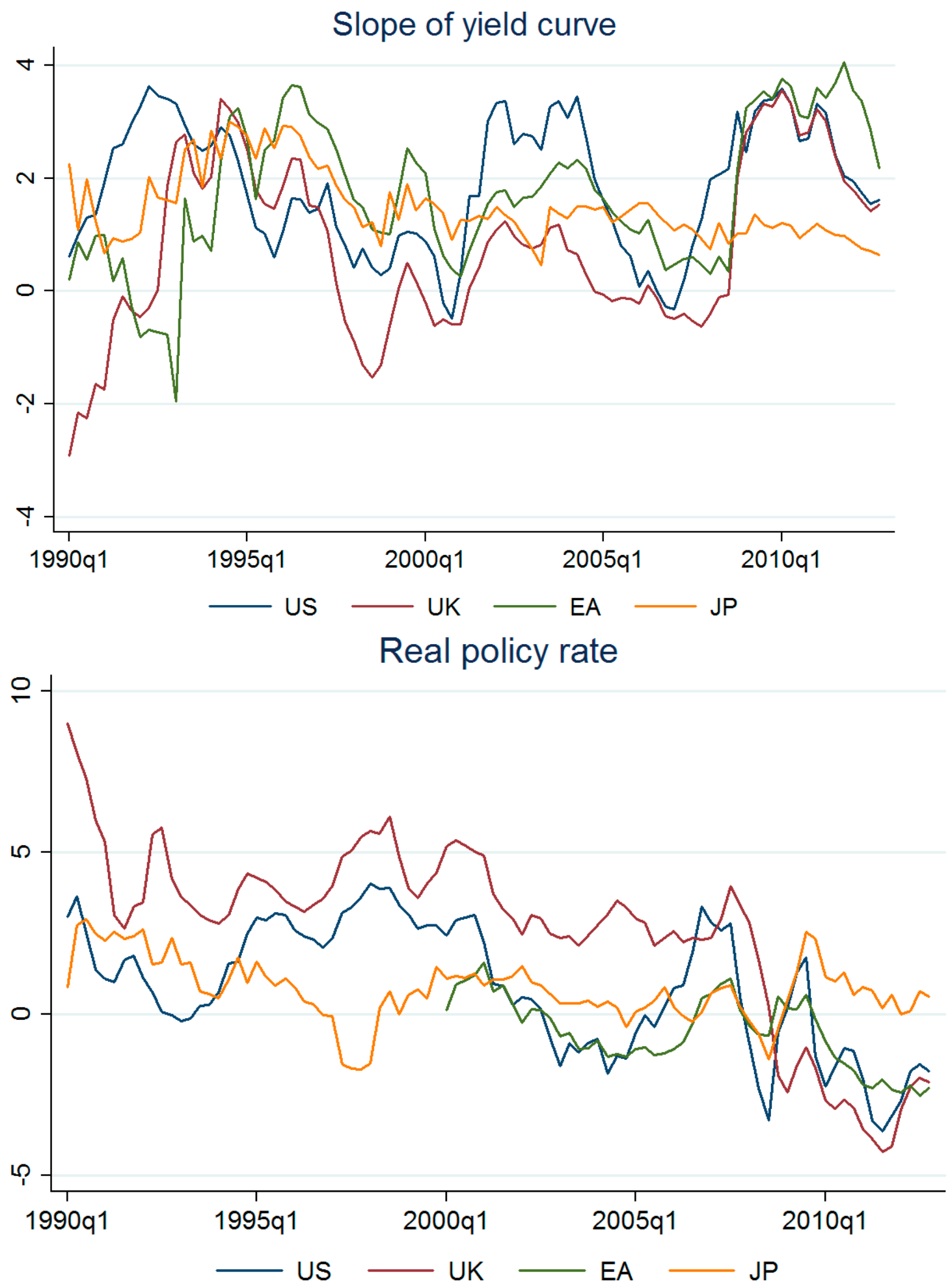


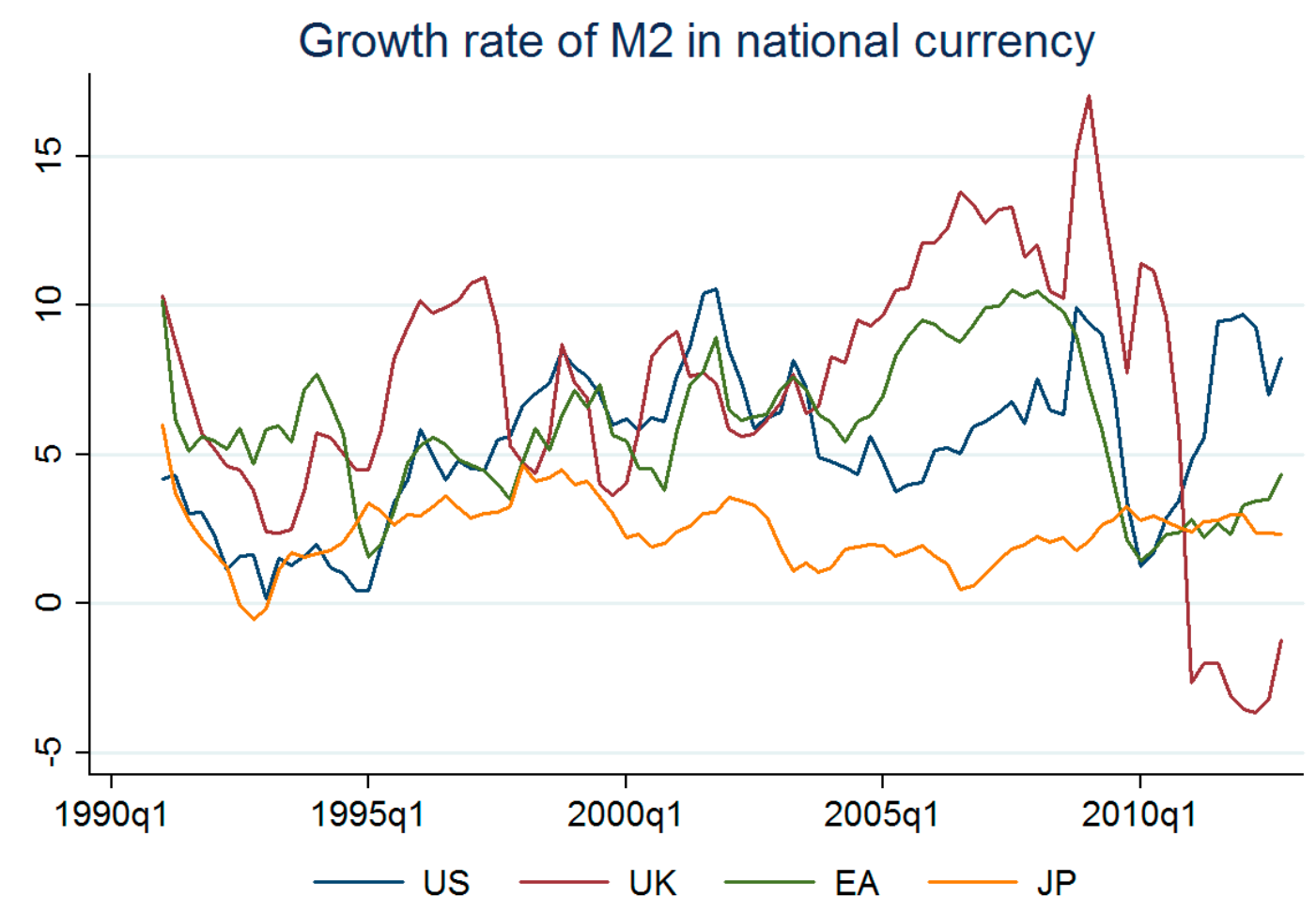

